\title{
Mosque Architecture in Cyprus-Visible and Invisible Aspects of Form and Space, 19th to 21st Centuries
}

\author{
Marko Kiessel ${ }^{1, *}$ and Asu Tozan ${ }^{2}$ \\ 1 Department of Archaeology and History of Art, Faculty of Arts, Arkin University of Creative Arts \& Design, \\ Kyrenia 99300, Mersin 10, Turkey \\ 2 Department of Interior Architecture, Faculty of Architecture, Eastern Mediterranean University, Famagusta \\ 99450, Mersin 10, Turkey; asu.tozan@emu.edu.tr \\ * Correspondence: marko.kiessel@arucad.edu.tr
}

check for updates

Citation: Kiessel, Marko, and Asu Tozan. 2021. Mosque Architecture in Cyprus-Visible and Invisible Aspects of Form and Space, 19th to 21st Centuries. Religions 12: 1055. https://doi.org/10.3390/rel12121055

Academic Editor:

Iakovos Potamianos

Received: 29 September 2021

Accepted: 28 October 2021

Published: 29 November 2021

Publisher's Note: MDPI stays neutral with regard to jurisdictional claims in published maps and institutional affiliations.

Copyright: (c) 2021 by the authors. Licensee MDPI, Basel, Switzerland. This article is an open access article distributed under the terms and conditions of the Creative Commons Attribution (CC BY) license (https:// creativecommons.org/licenses/by/ $4.0 /)$.

\begin{abstract}
A comprehensive analysis of Cypriot mosque architecture between the 19th and 21st centuries, from the Ottoman and British colonial periods to the present, does not exist. The phase after 1974, after the division of the island into a Turkish Cypriot, predominantly Muslim north and a Greek Cypriot, mainly Christian south, is especially insufficiently studied. This paper aims to interpret Cypriot mosque architecture and its meaning(s) through a comparative analysis, considering cultural, religious, and political developments. Based on an architectural survey and studies about Muslim Cypriot culture, this study investigates formal and spatial characteristics, focusing on the presence/absence of domed plan typologies and of minarets which, as visual symbolic markers, might express shifting cultural-religious notions and/or identities. Inconspicuous mosques without domes and minarets dominate until 1974. However, with the inter-communal tensions in the 1960s, the minaret possibly became a sign of Turkish identity, besides being a cultural-religious marker. This becomes more obvious after 1974 and is stressed by the (re)introduction of the dome. Since the late 1990s, an ostentatious and unprecedented neo-Ottoman architecture emphasizes visible and invisible meanings, and the Turkish presence in Cyprus stronger than before. The new architectural language visually underlines the influences from Turkey that North Cyprus has been experiencing.
\end{abstract}

Keywords: Cyprus; mosque; architecture; Muslim culture; Turkey; vernacular; neo-Ottoman; neovernacular; religious place making; identity

\section{Introduction: Muslim Culture in Cyprus}

Cyprus was part of the Greek-speaking Byzantine world of the eastern Mediterranean from the 4 th century to 1191 . The Byzantine rule was briefly disturbed by Arabic invasions in the mid-7th century during which, according to one legend, the foster aunt of the prophet died accidentally close to the Larnaca salt lake where her shrine is venerated. After 1191 the island fell to the Frankish aristocratic house of Lusignan. Cyprus owes a remarkable corpus of Byzantine and Gothic ecclesiastical and secular architecture to both of these periods. In 1489 , Venice took over control and responded to the expansion of the Ottoman armies with a considerable renewal of the fortifications of the harbor cities Famagusta and Kyrenia, and of the inland capital Nicosia, the latter project reflecting the ideal city planning of the Renaissance (Papacostas 1999; Bağişkan 2009, pp. 51-52; Coureas et al. 2012). Yet, by 1571, Cyprus fell to Sultan Selim II, and remained under Ottoman rule until 1878, when the island was first leased to the British. Cyprus experienced once again an architectural (and urban) transformation through new building types, such as mosques, hamams, and hans (Rizopoulou-Egoumenidou 2012).

\subsection{9th Century to 1960: From the Late Ottoman Rule to the End of British Colonial Rule}

The Turkish Cypriot community goes back to the Ottoman conquest. 'Very little' has been investigated or published on its faith and practices (Hatay 2015, p. 44). Cyprus 
was populated by about 30,000 Muslims (35\% of the population) during the first half of the 19th century (Nevzat and Hatay 2009, p. 912). The majority of the population were Greek Cypriots. Many (Muslim) villages were remotely located, not equipped with a mosque, nor visited regularly by an imam (Nevzat and Hatay 2009, pp. 914-15; see also Bağişkan 2009, pp. 14-15). Apart from the institutionalized orthodox Sunni Islam, dominant in towns, a 'folk' version of Islam was widespread in rural areas that also included practices 'shared with Christian neighbours' (Nevzat and Hatay 2009, pp. 912-13). After Ottoman reforms in 1839 and 1856 the unorganized and rather unorthodox 'folk Islam' [sic] and a 'Sufi Islam' [sic], that was institutional but shared unorthodox practices with 'folk Islam', were institutionally suppressed in Cyprus, resulting in the decline of Islamic practice by the mid-19th century, which prepared the ground for secularist Kemalism (named after Mustafa Kemal, also known as Atatürk) in the 1920s and 1930s, according to Nevzat and Hatay (2009, pp. 912-13) and Hatay (2015, p. 43).

Whereas Latin churches in larger towns had usually been converted to mosques after 1571, as in Nicosia and Famagusta, including the addition of tall minarets and the insertion of a mihrab (Rizopoulou-Egoumenidou 2012, p. 274), the majority of the (village-) mosques did not feature a minaret in the 19th century (An 2016, p. 7). Instead, they were often equipped with an exterior staircase reaching to a platform at the roof level from where the imam called to prayer (Bağişkan 2009, pp. 14-15). All religious buildings were controlled by a secular administration under the Evkaf Ministry since 'Sultan Mahmut II. had centralized the vakıfs [pious foundations] and established a new Directorate/Ministry of Evkaf, a term that is used as the plural of vakıf and that denominates the organization that is responsible for vakıf affairs' (Nevzat and Hatay 2009, pp. 913-14).

The Turkish Cypriot community identified itself as Ottoman or Muslim before the rise of Turkish nationalism in Anatolia at the beginning of the 20th century (Hatay 2008, p. 148). However, the developing Greek Cypriot nationalism that called for a union with Greece triggered an 'initially hesitant Turkism' (Nevzat and Hatay 2009, p. 917). The Kemalist transformations in Turkey after 1923, promoting secularism, modernization, and westernization, had a strong impact on Cyprus; the reception of the ideology of a Turkish secular nationalism by Muslim Cypriots was facilitated by the Ottoman reforms mentioned above, and by nearly five decades of (secular) modernization during British rule (Nevzat and Hatay 2009, pp. 918-19), which lasted from 1878 to 1960, and which considerably affected government, education, health, economy, urbanism, rural development, and architecture (Schaar et al. 1995; Tozan 2008; Markides 2012). Calls for the recognition of their Turkish nationality and for a national instead of religious education followed (Hatay 2008, p. 149), so that an 'already neglected Islamic education in the island entered a further period of decline.'

Nevertheless, as the colonial administration tried to suppress nationalist tendencies in the Greek and Turkish communities, it tried to strengthen religion in education, leading to the contradictory situation of medreses being closed in Turkey in 1924, while the Evkaf administration suggested establishing a new theological school in Nicosia (Nevzat and Hatay 2009, p. 920). ${ }^{1}$ However, the majority of Turkish Cypriots had embraced Kemalist Turkish nationalism by the time of Cyprus's independence from colonial rule in 1960. This development, which had begun in the 1920s, was also driven by 'increasing Greek nationalism and violence in the 1950s' (Hatay 2008, p. 149).

An event in 1956 exemplifies the level of secularization of the Turkish Cypriot community. After control of the Evkaf was given to the Turkish Cypriots, the issue of financing the construction of an International Style hotel in Nicosia, the current Saray hotel, was more important than repairing mosques (Nevzat and Hatay 2009, p. 922). ${ }^{2}$ In a similar light, the renaming in 1954 of the Aysofya mosque - the originally medieval Latin cathedral St. Sophia and crowning church of the kings of Cyprus from the house of Lusignan-to Selimiye mosque, in honor of the Ottoman sultan Selim II, the conqueror of Cyprus, has to be seen. ${ }^{3}$ 


\subsection{0-1974: Cyprus's Independence Years to the Division of the Island}

'Turkification' became most intense during these years of intercommunal fighting after 1960 (Hatay 2008, p. 150). Islam, however, did not play a major role, according to Nevzat and Hatay, contrary to the situation on the Greek Cypriot side, where the emphasis on religion was considerable (Nevzat and Hatay 2009, p. 925). Moreover, church architecture played an important role in the conflict with the British colonial power according to Kiessel and Tozan, reflecting 'Greekness' through a revival of Byzantine typologies since the 1930s (Kiessel and Tozan 2014, pp. 167-70, figs. 9-13 and 16). This phase ended with the Turkish military intervention in 1974, which led to the separation of the communities and to the Turkish control of the northern part of Cyprus (Asmussen 2008, pp. 272-73). By 1974, approximately 300 mosques existed in Cyprus (An 2016, p. 8).

\subsection{4-2001: North Cyprus before Turkey's Governments Led by the Justice and Development Party (AKP) in Turkey}

Eighty-four mosques existed in the northern part of the island before its division in 1974 (Dayığlu and Hatay 2014, p. 161). A process of attempted Islamization began after the military intervention, during which 48 churches were transformed into mosques (An 2016; Day1oğlu and Hatay 2014, p. 161). However, despite the extent to which Islam was promoted by the Turkish authorities—by providing imams and funding-it does not compare with the extent to which emphasis was put on the Cypriots' Turkish identity through 'religious references, symbols and buildings', according to Nevzat and Hatay (2009, p. 925).

According to An (2016, p. 9), nine new mosques were built between 1974 and 2002 and financed by the Turkish embassy in Nicosia (see also Tastekin 2021). According to data provided to the authors by the Evkaf Construction Department (2021), altogether 15 new mosques were constructed under its supervision until 2001. ${ }^{4}$ Yet, considering the time span of 27 years, this means that 0.7 mosques per annum were built, which is not a considerable number. According to Zencirci, the traditional 'heritage discourse of secular nationalism [in Turkey] which sought to disassociate Turkish national identity from Islam as well as the Ottoman past' made way for a new interpretation of national identity that fused 'Turkism' with Islam (Zencirci 2014, pp. 6-7). Whether or not this changing discourse also played a role in North Cyprus cannot be confirmed on the basis of the number of these mosques.

Religion played a stronger role for the Turkish immigrants who came to Cyprus after 1974. ${ }^{5}$ For Turks from the Black Sea region, a rather 'orthodox Islam still occupies a central place in their daily lives.' However, the second (and third) generation(s) of Turks from other areas of origin, born in Cyprus, assimilated into a local Turkish Cypriot culture in which Islam still does not play a significant role (Nevzat and Hatay 2009, p. 927).

\subsection{2-2021: North Cyprus during Governments Led by the AKP in Turkey}

The Evkaf, currently called the Waqfs Administration and Religious Affairs Office, owns all the religious buildings in the island's north (Dayığlu and Hatay 2014, p. 157). However, $95 \%$ of the cost of mosque construction, maintenance and staffing is provided by Turkey, via the Turkish embassy in Nicosia (Day1oğlu and Hatay 2014, p. 161; Tastekin 2021). As of 2021, 45 new mosques were built since 2002, according to M. Hatay (Tastekin 2021). According to data provided by the Evkaf Construction Department (2021), the number is $52 .{ }^{6}$ This means that 2.7 mosques per annum were built during the last 19 years, which is a considerable increase compared to the phase 1974-2001.

Wherever new mosques had been built, converted churches were abandoned (Dayığlu and Hatay 2014, p. 161). According to A. Dayığlu, these new mosques serve 'Turkish settlers' [sic] who amount to a fourth of North Cyprus's population and who are more conservative (Tastekin 2021), whereas Nevzat and Hatay state that the second generation of the immigrants was conversely 'assimilated' to Cypriot secular customs (Nevzat and Hatay 2009, p. 927). 
The wider background of the increase in the number of mosques might be the fact that, according to Zencirci, the Justice and Development Party (AKP), after its election in 2002, 'reproduced Turkish national identity along Ottoman-Islamic lines' in Turkey (Zencirci 2014, p. 3). This approach led to, according to Sonmez (2021), an '[...] unprecedented expansion of religious infrastructure and religious education' that mirrors ambitions to raise "pious generations". The expansion of religious infrastructure has also become a foreign policy instrument of 'soft power' which is run by the Directorate of Religious Affairs (Diyanet), in the form of a state-sponsored international mosque-building program (Seibert 2015). The Diyanet foundation (TDV) claims responsibility for the construction of more than 100 mosques and educational buildings in 25 other countries (Seibert 2015; Sonmez 2021).

Although North Cyprus has been used as a 'lab for [...] religious transformation policies', according to H. Kahvecioğlu (Tastekin 2021), the construction of new mosques might not yield the targeted results, because—as Tastekin notes (2021)—the concept of raising 'pious generations' has been met with resistance in North Cyprus, where a very moderate Islam is practiced.

\section{Mosque Architecture in Cyprus, 19th to 21st Centuries: Aim and Method of Research}

Thanks to Bağişkan (2009), a detailed architectural and historical study about individual mosque buildings built before 1974 is available. However, it does not include the developments after 1974, apart from the cases of later additions of minarets. Furthermore, it does not provide an interpretation of possibly invisible meanings, and does not closely relate architecture to the cultural, religious, and political developments as outlined above. An (2016) and other cited sources link these developments with statistics about the increasing number of mosques until 2021 but, apart from An, they do not refer to the architectural aspects. Finally, An's contribution to the subject (An 2016, pp. 9-10) is to superficially define some of the mosques discussed below, namely the Nurettin Ersin Paşa mosque in Kyrenia, as 'Anatolian', and the Hala Sultan mosque in Nicosia-Haspolat as a 'replica' of the Selimiye mosque in Edirne.

Therefore, we aim to interpret-through a comparative analysis—mosque architecture in Cyprus and its visible and/or invisible meaning(s) against the background of the cultural, religious, and political developments introduced above. The years of 1878 (the beginning of the British colonial period), the 1920s (the beginning of Kemalism in Turkey), 1974 (the division of Cyprus into a northern Turkish Cypriot and a southern Greek Cypriot part), and 2002 (the beginning of a now 19-year-long conservative-religious government in Turkey) are considered as possible turning points. Three basic formal and spatial criteria (the visible aspects of Cypriot sacred Muslim buildings) and their possible meaning(s) (the rather invisible aspects of these sacred buildings) were singled out:

(a) The minaret might function simply as visible marker of a mosque, or as culturalreligious (Muslim) statement, especially in a mixed society (Grabar 2005, p. 44; Hillenbrand 2010, p. 46). In the case of the mixed Greek and Turkish Cypriot society, it might also go beyond the expression of Muslim identity and emphasize "being Turkish" ${ }^{7}$, when considering the widespread absence of minarets prior to 1974, especially in villages, and the subsequent addition of minarets after 1974 (see details in the following section);

(b) The classic (Ottoman-Anatolian) plan typology with a central dome ${ }^{8}$-despite being very rare in Cyprus's Ottoman past and before 1974-might stress more strongly the Ottoman-Turkish heritage and presence in Cyprus, when compared to the Cypriot vernacular mosque typology. Like the minaret, this typology might also be related to the expression of Turkish identity rather than only conveying 'being Muslim', when considering that the (central) dome was reintroduced to mosque architecture on a large scale in the decades after 1974 (see details in the following section);

(c) The Cypriot vernacular plan typology with its rectangular hall and saddle- or flat roof (see details in the following section), which, when compared to the domed plan 
typology, naturally represents the local, but which in recent decades might even emphasize 'Turkish Cypriot' rather than 'Turkish Anatolian'.

Each of the introduced buildings is either typical of a series of mosques or unique, but all examples demonstrate representative formal and/or spatial features that we classified as: vernacular, neo-vernacular, Ottoman, neo-Ottoman, church conversion, or modern (Table 1; Figure 1). The statistics we created are mainly based on data about individual mosques provided by Bağişkan (2009) and the Evkaf Construction Department (2021) in Nicosia. Details and further sources are mentioned in the subsections below.

Table 1. Mosques in Cyprus, 19th to 20th centuries.

\begin{tabular}{|c|c|c|}
\hline Type/Style & Main Mosques Discussed in Text & Features/Remarks \\
\hline \multirow{2}{*}{$\begin{array}{c}\text { Vernacular } \\
\text { (19th to 20th centuries) }\end{array}$} & Yedikonuk/Ephtakomi & $\begin{array}{l}\text { Mosque function abandoned. Rectangular prayer hall, flat } \\
\text { saddle roof, no minaret, two inner arches from prayer to } \\
\text { front wall, three bays, mihrab in central bay. }\end{array}$ \\
\hline & Kyrenia, Ağa Cafer Paşa mosque & $\begin{array}{l}\text { Rectangular prayer hall, flat saddle roof, minaret, arcaded } \\
\text { front portico with three pointed arches, three inner arches } \\
\text { from prayer- to front wall, four inner bays. }\end{array}$ \\
\hline $\begin{array}{l}\text { Neo-vernacular } \\
\quad \text { (since 2015) }\end{array}$ & Type C: Akova/Gypsou & $\begin{array}{l}\text { Rectangular prayer hall, asymmetric saddle roof, minaret, } \\
\text { arcaded front portico with five pointed arches, four inner } \\
\text { pointed arches from prayer to front wall, five bays, mihrab } \\
\text { in central bay, portico, and details like window } \\
\text { frames/arches cladded with imitation of ashlar stones. }\end{array}$ \\
\hline \multirow{2}{*}{$\begin{array}{c}\text { Ottoman } \\
\text { (16th and 19th centuries) }\end{array}$} & Nicosia, Arab Ahmet Paşa mosque & $\begin{array}{l}\text { Square prayer hall, octagonal tambour with four arched } \\
\text { windows alternating with four semidomes, central dome, } \\
\text { minaret, arcaded front portico with three pointed arches } \\
\text { and three small domes. }\end{array}$ \\
\hline & $\begin{array}{l}\text { Larnaca, mosque of Hala } \\
\text { Sultan Tekke }\end{array}$ & $\begin{array}{l}\text { Square prayer hall, octagonal tambour with a semidome } \\
\text { above every corner of the square, central dome, minaret, } \\
\text { arcaded front portico with four pointed arches. }\end{array}$ \\
\hline \multirow{3}{*}{$\begin{array}{l}\text { Neo-Ottoman } \\
\text { (since 1998) }\end{array}$} & $\begin{array}{l}\text { Type B: } \\
\text { Kyrenia, Nurettin Ersin Paşa } \\
\text { mosque, } \\
\text { Yedikonuk/Ephtakomi, } \\
\text { Doğanköy (Kyrenia) }\end{array}$ & $\begin{array}{l}\text { Square prayer hall with a central dome and } \\
\text { lateral/flanking extensions, covered by semidomes and } \\
\text { small domes, arcaded front portico with three pointed } \\
\text { arches/two lateral domes, one or two minarets, } \\
\text { historicizing exterior and interior detailing, such as } \\
\text { extensive interior blue-colored tiling (Kyrenia), window } \\
\text { frames, cornices, arches cladded with imitation of (local) } \\
\text { ashlar stone. }\end{array}$ \\
\hline & $\begin{array}{l}\text { Type A: } \\
\text { Kaleçik/Gastria }\end{array}$ & $\begin{array}{l}\text { Square prayer hall, octagonal tambour, minaret, central } \\
\text { dome, arcaded front portico with three (pointed) arches } \\
\text { and three domes, historicizing exterior and interior } \\
\text { detailing, such as window frames, cornices, arches } \\
\text { cladded with imitation of (local) ashlar stone. }\end{array}$ \\
\hline & $\begin{array}{l}\text { Haspolat/Mia Milia, Hala Sultan } \\
\text { mosque (2019) }\end{array}$ & Replica of the Selimiye mosque, Edirne, Turkey. \\
\hline $\begin{array}{l}\text { Church conversion } \\
\quad \text { (after 1974) }\end{array}$ & $\begin{array}{l}\text { Yedikonuk/Ephtakomi, St. George } \\
\text { Zümrütköy/Katokopia, BVM }\end{array}$ & $\begin{array}{l}\text { Historicist neo-Byzantine style. Mosque function } \\
\text { abandoned. Replaced by neo-Ottoman mosque, type B. } \\
\text { Modern neo-Byzantine style. Functioning as mosque. } \\
\text { Campanile functions as minaret, mihrab installed in } \\
\text { southern cross-arm. }\end{array}$ \\
\hline $\begin{array}{c}\text { Modern } \\
\text { (1991 and 2017) }\end{array}$ & $\begin{array}{l}\text { Dipkarpaz/Rizokarpaso } \\
\text { Famagusta, Selim II. mosque }\end{array}$ & $\begin{array}{l}\text { Square prayer hall, central dome over tambour, arcaded } \\
\text { front portico with five pointed arches and five small } \\
\text { domes, minaret, rather modern aesthetic. } \\
\text { Square prayer hall, pyramidal roof with exposed steel } \\
\text { structure, naturally lighted mihrab niche, minaret. }\end{array}$ \\
\hline
\end{tabular}




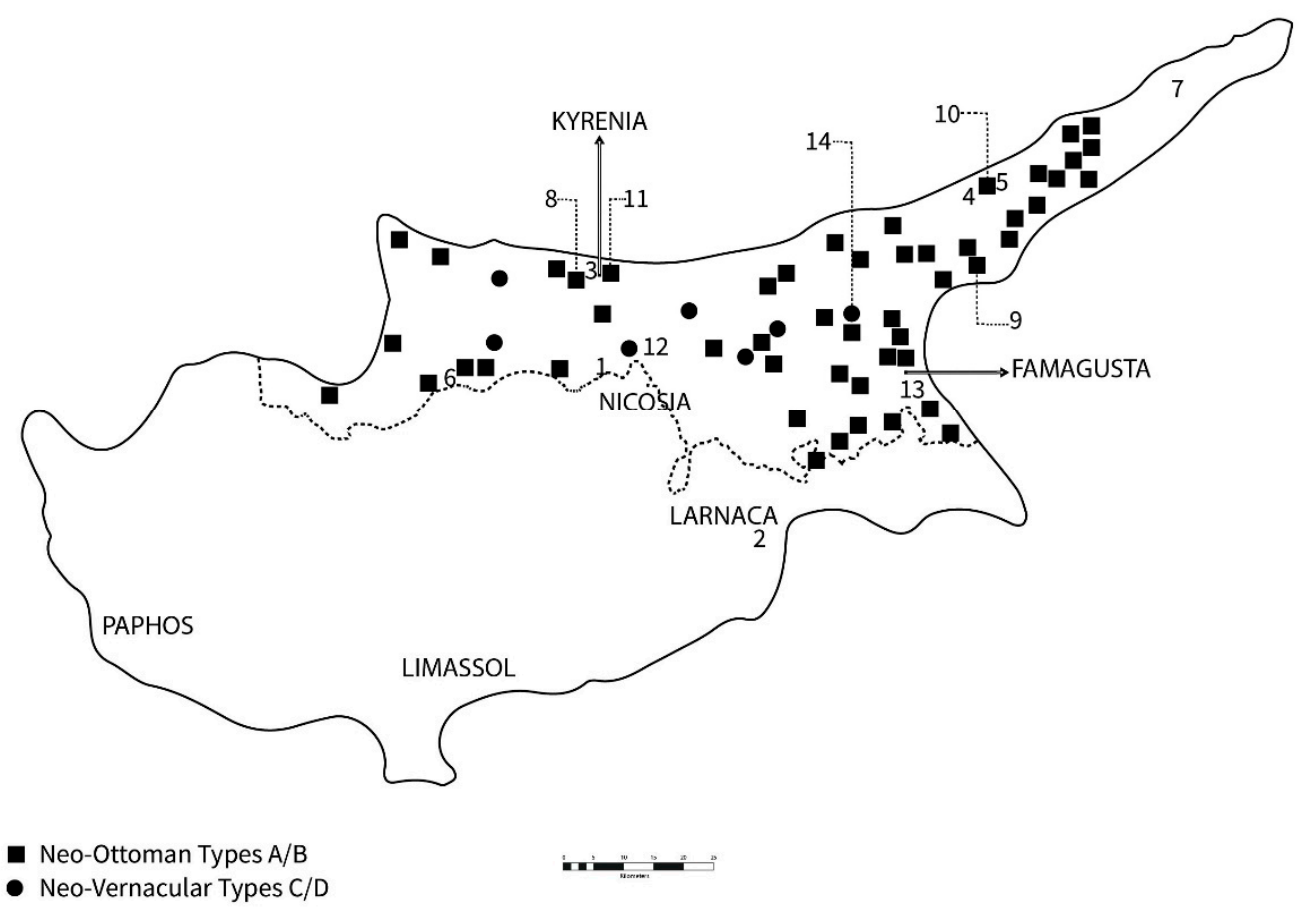

Figure 1. Cyprus. Location of the mosques discussed in detail in the text (1-14), and of the neoOttoman and neo-vernacular, types A-D (map: authors and Mojtaba Karimnezhad). 1: Arab Ahmet Paşa mosque (Ottoman); 2: Hala Sultan Tekke mosque (Ottoman); 3: Ağa Cafer Paşa mosque (vernacular); 4-5: Yedikonuk's former mosques (vernacular/church conversion); 6: Zümrütköy (church conversion); 7: Dipkarpaz mosque (modern); 8: Nurettin Ersin Paşa mosque (neo-Ottoman, type B); 9: Kalecik mosque (neo-Ottoman, type A); 10: Yedikonuk mosque (neo-Ottoman, type B); 11: Doğanköy mosque (neo-Ottoman, type B); 12: Hala Sultan mosque (neo-Ottoman, replica of Selimiye mosque, Edirne); 13: Selim II mosque (modern); 14: Akova mosque (neo-vernacular, type C).

\section{Mosque Architecture on Cyprus, 19th to 21st Centuries: Discussion and Results}

3.1. The 19th Century: Mosques in Cyprus from the (Late) Ottoman Period and the Beginning of British Rule

For buildings built before 1974, statistics about the number of mosques have been developed by the authors, based on the construction data on individual mosques and minarets provided by Bağişkan (2009). With the exception of at least nine uncertain cases, all of the currently existing 57 mosques that Bağişkan discusses go back to the first three quarters of the 19th century or earlier. However, a report on Evkaf properties from 1883 lists 81 mosques (Bağişkan 2009, p. 9). The numerical contradiction can be explained by the complete loss of some buildings and/or by the later complete replacement or rebuilding of some buildings, which would mean that these mosques are counted among the buildings of later periods.

One prominent example among the mosques of this period is the Arab Ahmet Paşa mosque in old-town Nicosia that dates 'very probably' to the 16th/17th centuries, with the last major interventions in 1845 (Bağişkan 2009, pp. 88-90, figs. 44 and 45, plan 10; Rizopoulou-Egoumenidou 2012, p. 277) (Figures 1 and 2a,b). Another is the mosque of the Hala Sultan Tekke in Larnaca, which dates from 1817 (Bağişkan 2009, pp. 53, 57, 60, plan 8, fig. 29) (Figure 1, Nr. 2). ${ }^{9}$ They are two of originally four domed mosques with a minaret, built before 1974 in a 'classical Ottoman style' (Bağişkan 2009, pp. 57, 88-90, 196-98, 207-9). They are, in our opinion, inspired by the Selimiye mosque in Edirne, the masterpiece of the work of architect Sinan. ${ }^{10}$ Their link to the Selimiye is an octagonal drum/tambour over a square prayer hall, where the drum displays an alternation of four semi-domes and four arched windows (Arab Ahmet Paşa mosque), or just four semi-domes (Hala Sultan Tekke mosque). The Arab Ahmet mosque is probably a deliberate architectural reference to the 
mosque in Edirne that was commissioned by Selim II, the conqueror of Cyprus. Moreover, the name supports this view, as Arab Ahmet Paşa was one of the commanders (beylerbeyi) in the conquest of Nicosia.

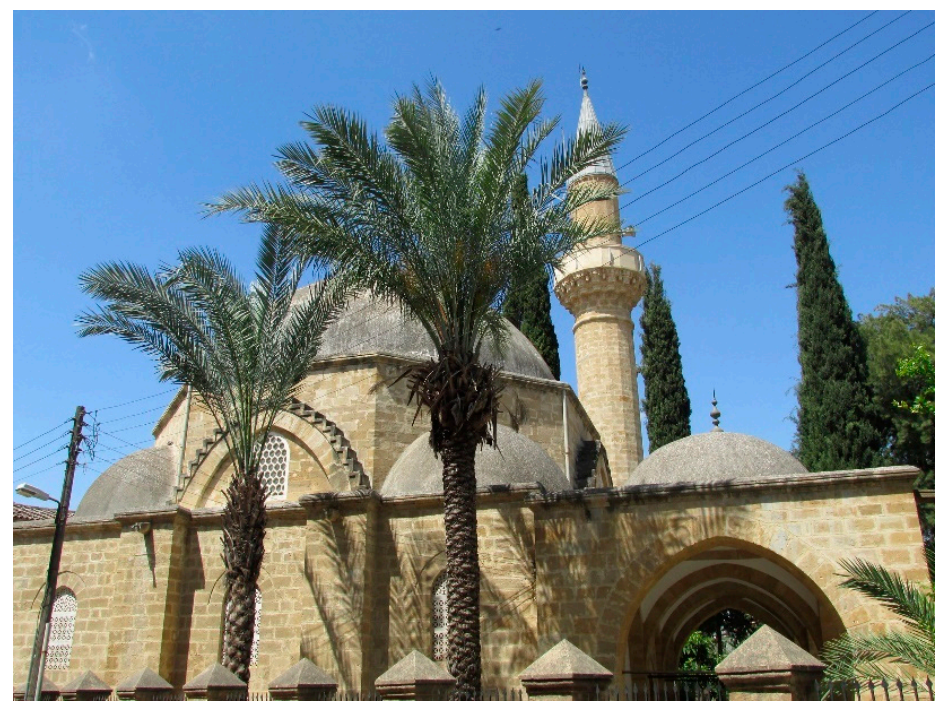

(a)

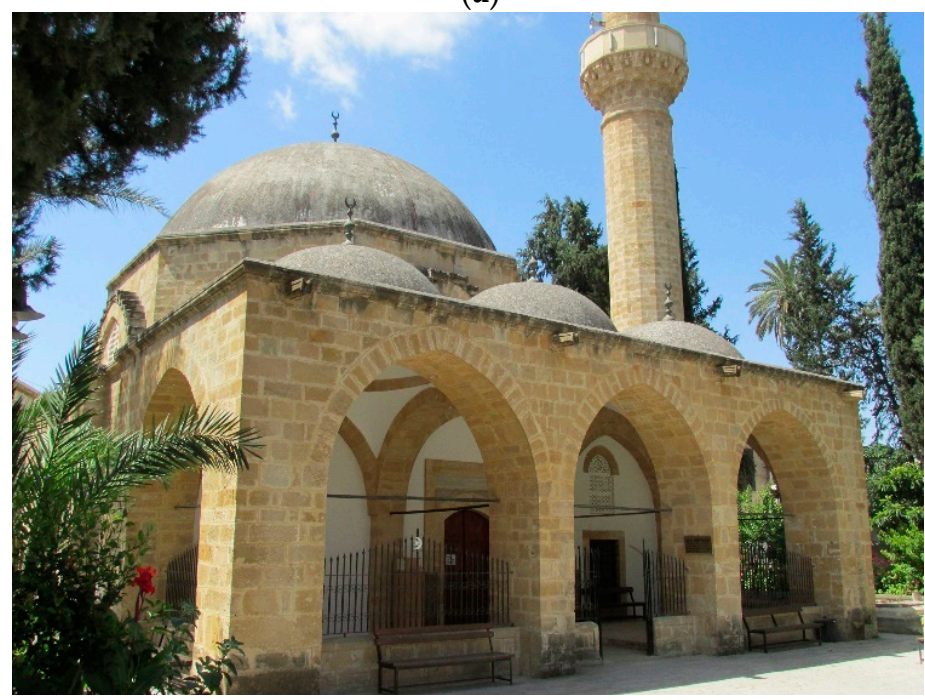

(b)

Figure 2. Nicosia, Arab Ahmet Paşa mosque, 16th/17th centuries and 1845 (Ottoman type): (a) lateral facade of the prayer hall and frontal portico; (b) front facade with arcaded portico (photos: authors).

The Ağa Cafer Paşa mosque in old-town Kyrenia (1589-90), featuring a minaret, was originally equipped with a dome, but in 1878-1880, at the very beginning of British rule (1878-1960), a flat saddle-roof was installed. A rectangular prayer hall is structurally characterized by three arches that span from the prayer to the front wall (Bağişkan 2009, pp. 196-98, figs. 141-43, plan 40) (Figure 3a-c). In this form, the mosque is a large example of the common Cypriot vernacular type that is usually lacking a minaret and that is equipped with a rectangular hall and a saddle (or flat) roof, and which frequently features several inner (pointed) arches, and at times an arcaded front portico-features that we filtered out through a thorough analysis of Bağişkan's data on individual mosques. 


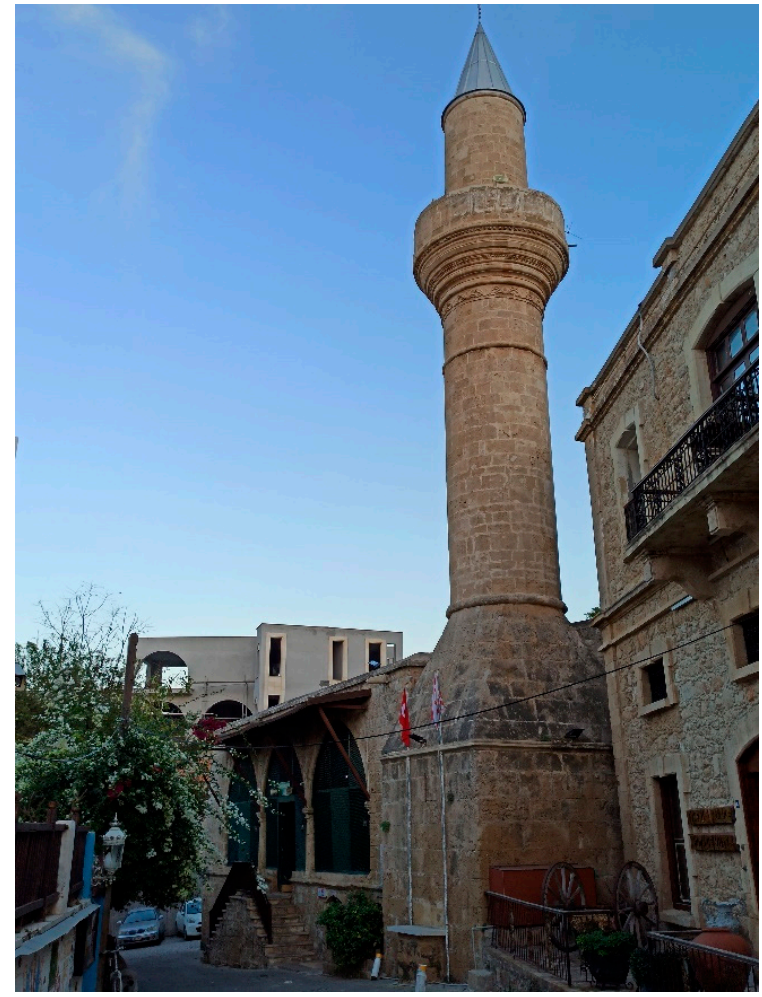

(a)

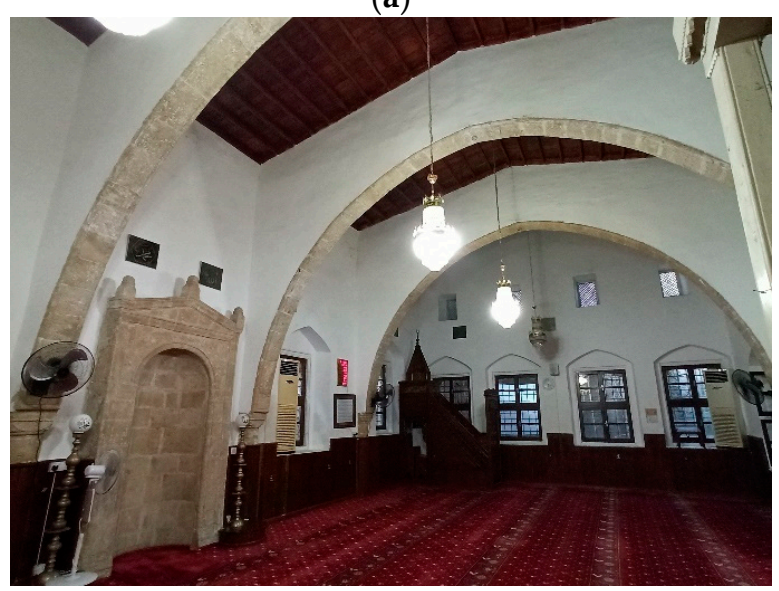

(b)

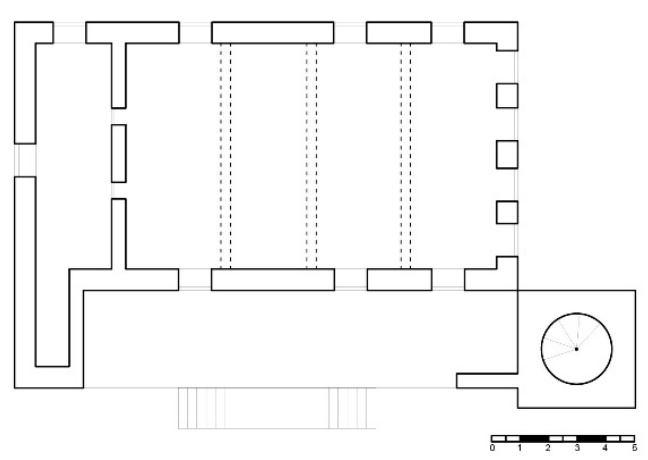

(c)

Figure 3. Kyrenia, Ağa Cafer Paşa mosque, late 16th century and 1878-80 (vernacular type): (a) entrance façade with arcaded portico; (b) interior with view onto mihrab and quibla on the left; (c) plan, based on Bağişkan (2009, p. 196, plan 40) (photos: authors; drawing: authors and Mojtaba Karimnezhad). 
When comparing the plans, exteriors, interiors, building techniques, and materials of vernacular mosques (Bağişkan 2009, pp. 139, 151, 155, 164, 174-75, with figures) with Cypriot vernacular house architecture (Ionas 2003, pp. 46-48, 53-55, 150-55, with figures), strong similarities, and possibly the influence of traditional residential architecture, become evident: both building types may feature an arcaded front portico, central door, rectangular space (flat saddle or flat roof), inner roof support/spatial subdivision by one pointed arch (in the case of houses), a row of wooden posts (houses) or a row of pointed arches (mosques) parallel to the rear and front wall; or the building types may feature a roof support/spatial subdivision by two (houses/mosques) or sometimes three or more (mosques) single arches which span from the rear to the front wall in regular intervals and thereby subdivide the interior usually into three bays, while the mihrab occupies the central bay.

\subsection{Mosques in Cyprus from the First Decades of the British Period at the Turn from the 19th to 20th Centuries}

Seventy-six additional, currently existing mosques date back to the last two and first two decades around the turn of the centuries, based on the data on individual buildings provided by Bağişkan (2009). They were partly newly built, and partly they replaced older buildings. None of them features a dome, and therefore they lack a typical Ottoman appearance. The majority belongs to the modest Cypriot vernacular type. Occasionally, in the larger towns, a stronger representativeness, mainly in terms of size, can be noticed, like in case of the the unique Sarayönü mosque from 1902 in old-town Nicosia, which was designed by a British architect exceptionally in a North-African style (Bağişkan 2009, pp. 124-29, figs. 65-67), while probably avoiding deliberately an Ottoman style. It features a large, rectangular, undivided prayer hall with horse-shoe arches as window frames and as elements of the front portico arcade. ${ }^{11}$ The Cypriot village mosques were usually not equipped with a minaret (An 2016, p. 7), but at times with a balcony or platform at the roof level from which the call for prayer was conducted, as in the example of Nergisli/Yenagra ${ }^{12}$ in the Famagusta district from 1902, the current minaret of which was added in 2005 (Bağişkan 2009, pp. 14-15, 257-58, fig. 215).

The small mosque of Yedikonuk/Ephtakomi, which was never equipped with a minaret according to oral history, has been missed by Bağişkan (2009) (Figures 1 and 4a,b). It features a rectangular prayer hall with flat saddle roof, two massive exterior buttresses at its southern and northern walls that support two interior arches, and a single door on its north wall with a decoratively carved frame. Above its segmental arch, an Arabic inscription survives that mentions the year 1290 (=A.D. 1884), according to verbal information from Mr. Mustafa H. Altan (the former director of the National Archive of North Cyprus), and that most likely refers to the construction date of the building. Apart from the bay with the door, the building's surface has been plastered over sometime later, meaning that details cannot be examined. The building belongs to the vernacular mosque type and is reminiscent of the traditional Cypriot house architecture, as described above. It is comparable in appearance and size to the mosques at Kalavaç/Kalyvakia and Mathiatis/Matiyat, Nicosia district, dating back to the 19th century and to 1913, respectively (Bağişkan 2009, pp. 169, 183, figs. 107 and 121). This mosque belongs to the phase when, as outlined in the introduction, the Turkish Cypriot community identified itself as Ottoman or Muslim rather than as Turkish. Furthermore, its inconspicuous architecture, just like the architecture of most mosque buildings of this period, expresses—if at all-nothing more than its affiliation with Muslim practice. Further (invisible) meanings beyond this basic meaning cannot be observed. 


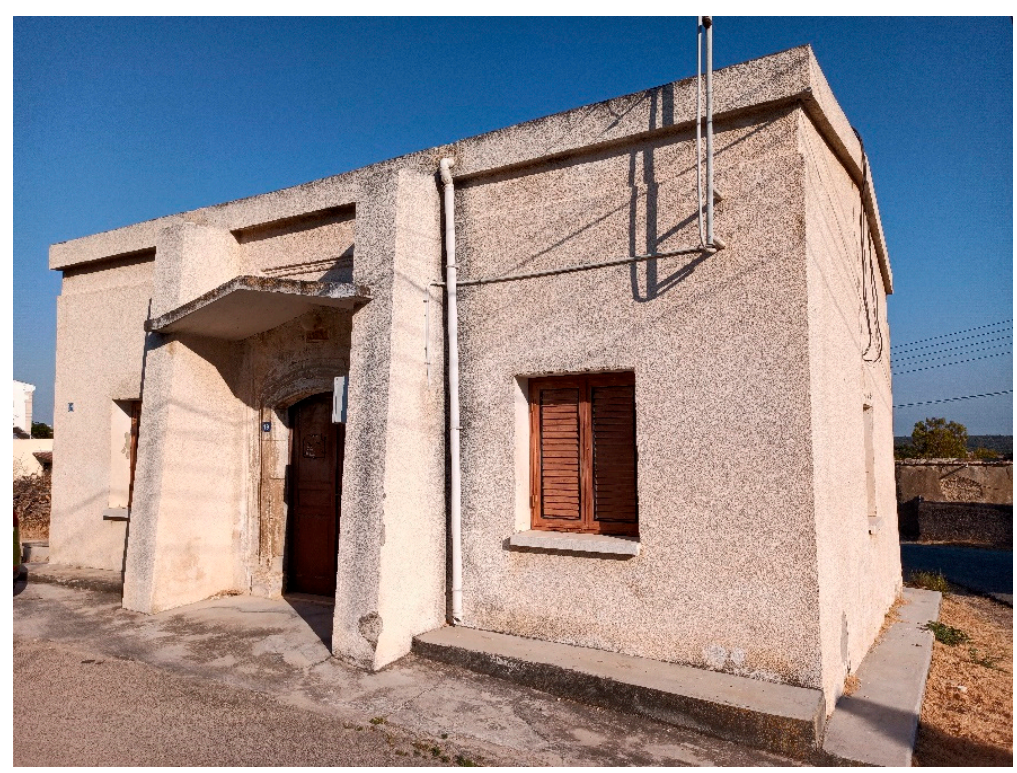

(a)

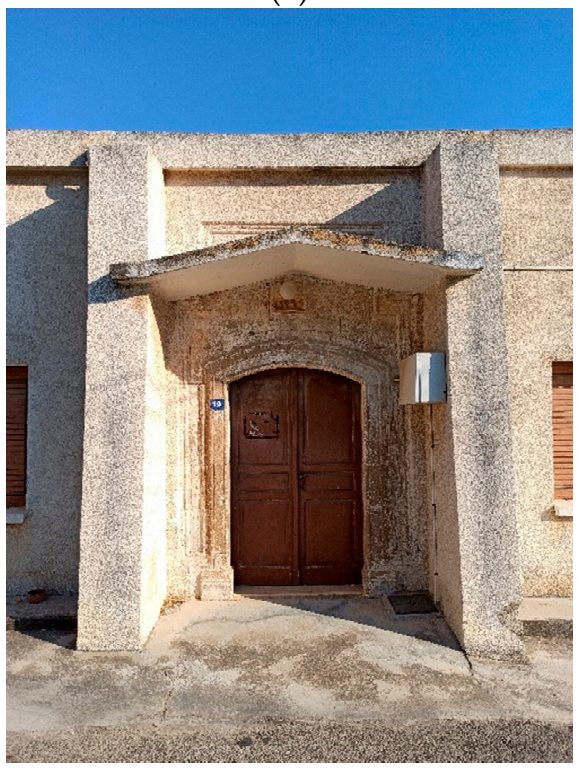

(b)

Figure 4. (a,b): Yedikonuk/Ephtakomi, former mosque (vernacular type), currently used as an educational space, 1884 (photos: authors).

3.3. The 1920s to 1974: Mosques in Cyprus from the Rise of Kemalism to the Division of the Island

Forty-one new mosques, some of which were newly built and others built to replace older buildings, belong to this phase. Among the newly built mosques of this period are seven village mosques based on a design of 1958 by Theodoros Photiadis, who regularly worked for Evkaf (Bağişkan 2009, pp. 242, 273). ${ }^{13}$ Unusual for vernacular mosques, this design of 1958 includes a minaret. It was implemented in variations, also two times without minaret, in seven villages from the early 1970s onward (Bağişkan 2009, pp. 252-53, fig. 203, pp. 273-74, fig. 240, p. 314, fig. 283, p. 318, fig. 293, pp. 327-28, fig. 299). In 1958 a Greek Cypriot architect would certainly not have intended to emphasize 'Turkishness' with this design, at a time when intercommunal clashes had already intensified. Possibly his client, the Evkaf, did but if so, remains in the dark. However, considering (a) the massive intercommunal tensions of the post-independence years from 1963 to 1974, (b) the development of a strong secular Turkish identity amongst Turkish Cypriots since the 1920s (Nevzat and Hatay 2009, pp. 918-19; Hatay 2008, p. 149), and (c) the actual application 
of this design with minaret to five buildings in the last years before 1974, we argue that these mosques possibly express 'Turkishness', rather than conveying religious meanings only. The same might be valid for six existing mosques to which, according to Bağişkan, minarets were newly added in the late 1960s and early 1970s (Bağişkan 2009, pp. 165, 169, 198-200, 200-1, 211, 234-36). ${ }^{14}$

However, before the late 1960s, no clear pattern for the existence or absence of minarets in the villages emerges. Was the minaret simply a visible marker of a mosque, rather than a cultural-religious statement or an expression of Turkish identity in mixed villages? Was it simply a sign of the availability/lack of financial means? Or a combination of several of these aspects? Bağişkan mentions the example of Kaleburnu/Galinoporni, where the minaret of 1968 was donated by a wealthy benefactor as the village was not able to afford it, while in Aynikola/Ayios Nikolaos the suggestion to add a minaret to a mosque in need of repair was raised by a Greek Cypriot stonemason in 1917 (Bağişkan 2009, pp. 244-46, 335-38). Both cases cannot simply and safely be interpreted as an enhanced expression of 'Turkishness'.

\subsection{4 to 2001: Mosques in North Cyprus before Turkey's AKP-Led Governments}

The authors' statistics for the years from 1974 to 2021 are based on data provided by the Evkaf Construction Department (2021), and on Tastekin (2021), An (2016), Day1oğlu and Hatay (2014), Nevzat and Hatay (2009), and Hatay (2008). Apart from conversions of churches, 18 new mosques were built in the phase 1974-2001, of which at least nine were financed-according to An (2016) - by the Turkish Embassy in Nicosia. We observed a widespread addition of minarets to existing village mosques in the Turkish north until 2007, based on the individual data provided by Bağişkan. ${ }^{15}$ The sizes of these 25 new minarets are often 'out of proportion' (Bağişkan 2009, pp. 150-51, 155-56, 168, 173, 184, 193-94, 212-13, 227-30, 232-34, 236, 246-58).

The successor to the previously discussed old mosque from 1884 in the center of the once Greek and Turkish village Yedikonuk/Ephtakomi was the converted church of St. George, which was in use until 2008 (Figures 1 and 5). Its obvious historicizing neo-Byzantine typology and morphology probably dates back to a design of Theodoros Photiadis, which was applied in variations all over the island and that is also a reflection of the anti-colonial Greek Cypriot attitudes prevalent since the 1930s (Kiessel and Tozan 2014, pp. 167-68, 170, figs. 9 and 10). With newly arriving Turkish immigrants who replaced the Greek villagers after 1974, the old mosque must have become too small. Similarly, as with after the Ottoman conquest of the island in 1571-apart from a possible display of power through the occupation of a Christian cult building — spatial demand played a major role in the conversion of churches to mosques that, nevertheless, continued to look like churches.

Another example of a conversion in 1974 is the former church of the Blessed Virgin Mary in Zümrütköy/Katokopia that had just been built a few years earlier, and in a more modern abstract Byzantine style (Kiessel and Tozan 2014, pp. 168-69, figs. 13 and 16) compared to the former church of St. George in Yedikonuk. In a kind of adaptive reuse, mihrab and minbar were accommodated in the southern cross-arm, ${ }^{16}$ while the icons were removed from the surviving wooden iconostasis (Figures 1 and 6a,b).

The mosque of Dipkarpaz/Rizokarpaso was built in $1991 .{ }^{17}$ Although it is an early example of the reintroduction of a central dome over a square prayer hall, for the case of North Cyprus it features a rare modern abstract aesthetic (Figures 1 and 7). The building is taller than the Orthodox cathedral, St. Synesios, and the effect of its size is increased by its location on top of a ridge behind the church. ${ }^{18}$ With the arrival of Turkish immigrants after 1974, Dipkarpaz became a unique case in North Cyprus of a once purely Greek Cypriot village that features a mixed population because parts of the Greek inhabitants chose not to resettle in the Republic of Cyprus (Asmussen 2008, p. 273). We argue that its domed typology, its size and location, coupled with the circumstance of a mixed village, are most likely meant to emphasize a Turkish (rather than Cypriot) and Muslim presence. 


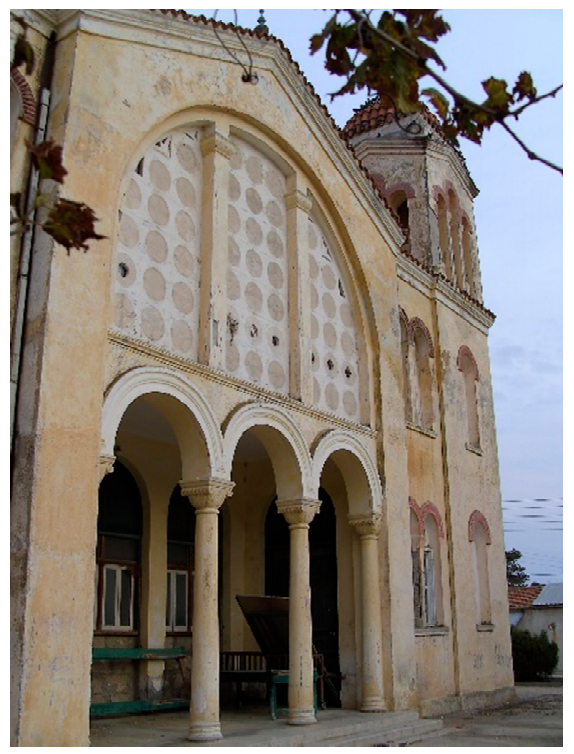

Figure 5. Yedikonuk/Ephtakomi, former church of St. George, converted to a mosque after 1974 (now unused), west façade (photo: authors).

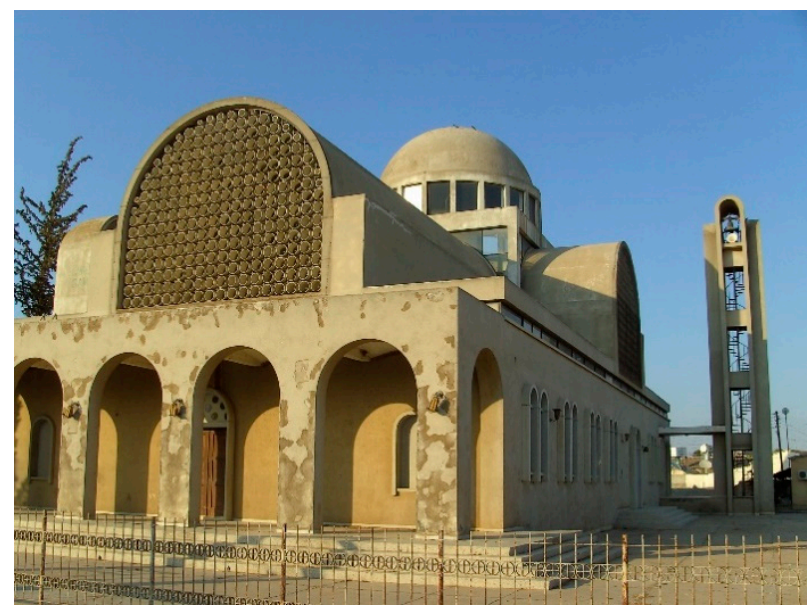

(a)

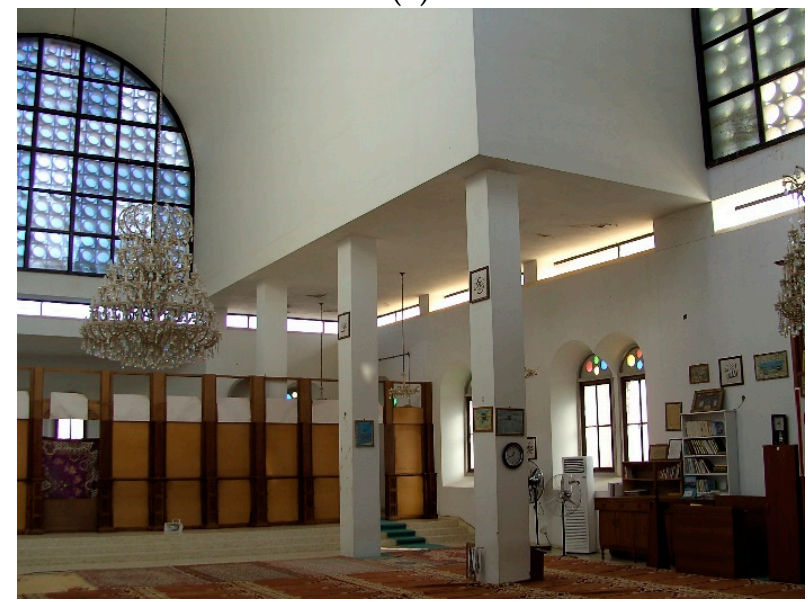

(b)

Figure 6. Zümrütköy/Katokopia, former church of the Blessed Virgin Mary, converted to a mosque after 1974: (a) west façade; (b) view from the crossing onto the disused Christian sanctuary and the southern cross-arm where the (not pictured) mihrab is installed (photos from 2014: authors). 


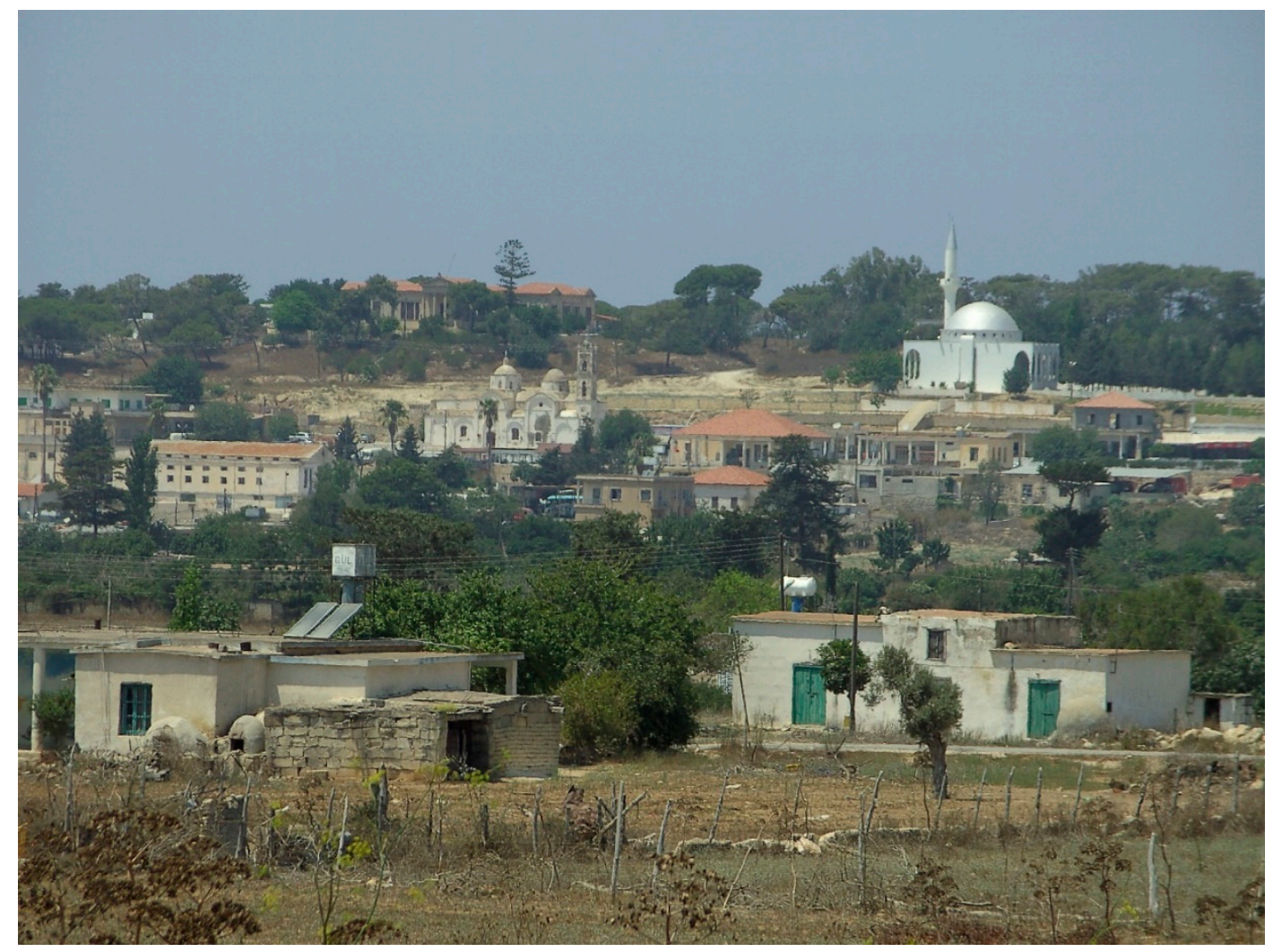

Figure 7. Dipkarpaz/Rizokarpaso, view from south-east. Top-right, the mosque of 1991 (modern type) with its mihrab in the center. Top-left, the church of St. Synesios (photo: authors).

The Nurettin Ersin Paşa mosque in Kyrenia (1999), ${ }^{19}$ named after a Turkish commander of the 1974 intervention forces, is a paradigm shift in the mosque architecture of North Cyprus (Figures 1 and 8a,b). It was 'presented as a gift' by the Turkish Diyanet foundation in collaboration with the local Evkaf, as stated in the inscription above the entrance, and financed by the Turkish embassy in Nicosia (An 2016, p. 9). It ostentatiously displays an 'Anatolian style' (An 2016, p. 9), more precisely a neo-Ottoman morphology, including interior traditional blue-colored ceramic tiling, in contrast to, for example, the comparatively modern aesthetics of the mosque of Dipkarpaz.

The form of the prayer hall that is accessed via an arcaded, three-bay entrance portico can be read as a variation of Sinan's Selimiye mosque in Edirne. ${ }^{20}$ The essential link is the octagonal drum underneath the central dome which defines an octagonal space in the interior (corresponding to the very core of the space of the Selimiye that is defined by its eight load-bearing columns) which is framed by an inner square space (Figures $8 a, b$ and $9 a$ ). Beyond the four slightly longer sides of the octagon (where the Selimiye displays arched tympana with windows on the level of its octagonal drum) the space is extended into four rectangular exedrae (Figure 9a). The exedrae are covered by a semi-dome, and mark the extension of an imaginary outer square. The feature of a mihrab being placed within a semi-domed exedra is another link with the Selimiye. The remaining four shorter sides of the octagon (where the Selimiye displays semi-domes on the level of the drum) are directed toward the four corners of the inner square. The resulting triangular spaces between the inner square and the octagon are covered by squinch-like elements which alternate with the four semi-domes (Figures $8 b$ and $9 a$ ). ${ }^{21}$ 


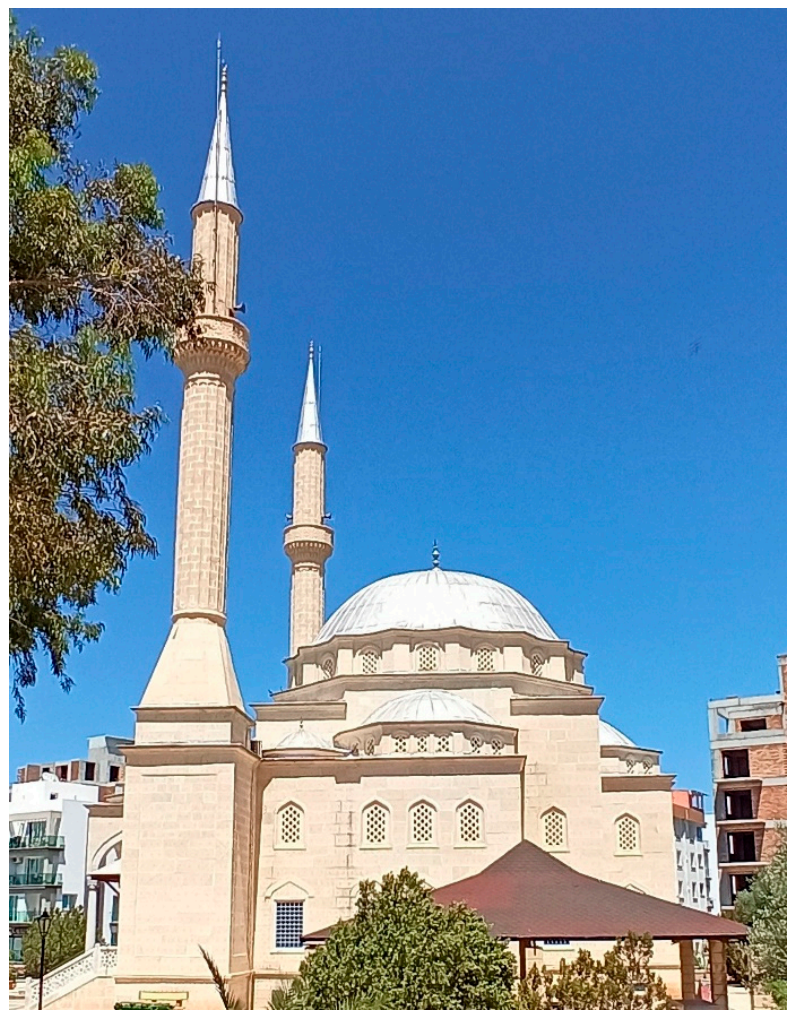

(a)

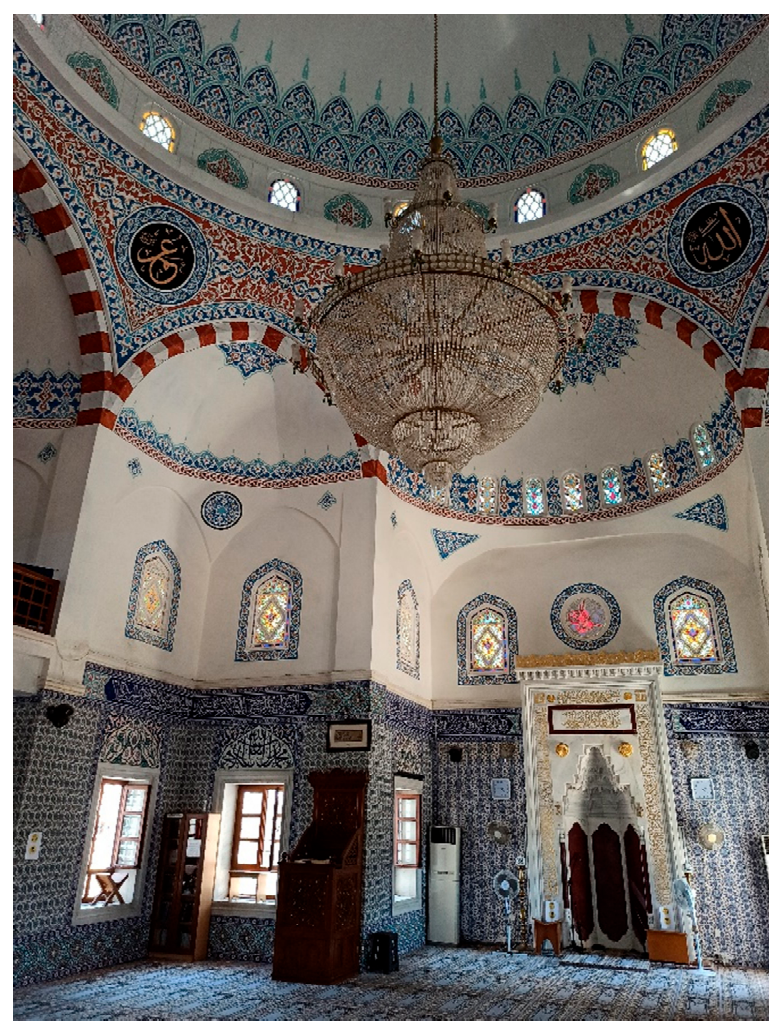

(b)

Figure 8. Kyrenia, Nurettin Ersin Paşa mosque (neo-Ottoman type), 1999: (a) west elevation; (b) view onto qibla and mihrab (photos: authors).

The Nurettin Ersin Paşa mosque served as a model for 'smaller [?] copies' (An 2016, p. 9), mainly in the years after 2002 (Figures 1 and 9a-c). In essence, their standardized 
design (type B) was provided to the Evkaf (most likely by the Diyanet foundation) but their design details, such as the cladding with local stone material, were slightly altered case-by-case by the Evkaf Construction Department (Evkaf Construction Department 2021). Yet another standardized, more simplified neo-Ottoman type (A) with a lesser spatial capacity has emerged since 1998, as seen for example in Kaleçik/Gastria (2013) (Evkaf Construction Department 2021) (Figures 1 and 10). It features a central dome over an octagonal drum without semi-domes and corner-triangles, and a square prayer hall that is also accessed via an arcaded, three-bay entrance portico.

As outlined above, according to Zencirci, the traditional heritage discourse of a secular nationalism in Turkey made way already before the 21st century (before the AKP came to power) for a new interpretation of national identity that fused 'Turkism' with Islam (Zencirci 2014, pp. 6-7). ${ }^{22}$ We argue that this Turkish discourse might also be visible in the Cypriot mosque architecture since the early 1990s (and was becoming more ostentatious by the end of the 20th century), considering the Turkish (financial) influence, the upgrading of older mosques with minarets, and the introduction of a neo-Ottoman morphology. In effect, these developments began to make Islam more visible in North Cyprus and gave it-through the neo-Ottoman morphology—a rather Anatolian than Cypriot appearance.

\subsection{2 to 2021: Mosques in North Cyprus during Turkey's AKP-Led Governments}

\subsubsection{Neo-Ottomanism}

As mentioned above, 52 new mosques were built since 2002. Based on the data from the Evkaf Construction Department, a majority of these (42 buildings) belong to the previously mentioned standardized neo-Ottoman types A and B, the latter being a copy of the Nurettin Ersin Paşa mosque from 1999 in Kyrenia. Type B (Figures 1 and 9a-c) is planned for larger communities, corresponding to its spatial capacity, whereas the simplified and smaller type A, as in Kaleçik/Gastria (Figure 10), is designed to serve smaller communities. ${ }^{23}$ An example of type B in Yedikonuk/Ephtakomi (Figures 1 and 9b) was completed in 2008 with the support of the Aid Committee of the Turkish embassy in Nicosia. ${ }^{24}$ The height of its minaret outmatches the size of its predecessor, the former church of St. George, that had been converted into a mosque after 1974, and which has been unused since the new mosque became operational.

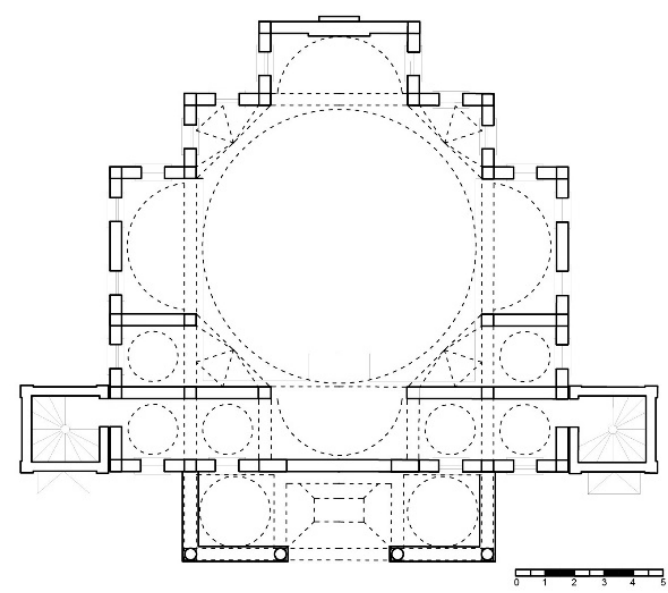

(a)

Figure 9. Cont. 


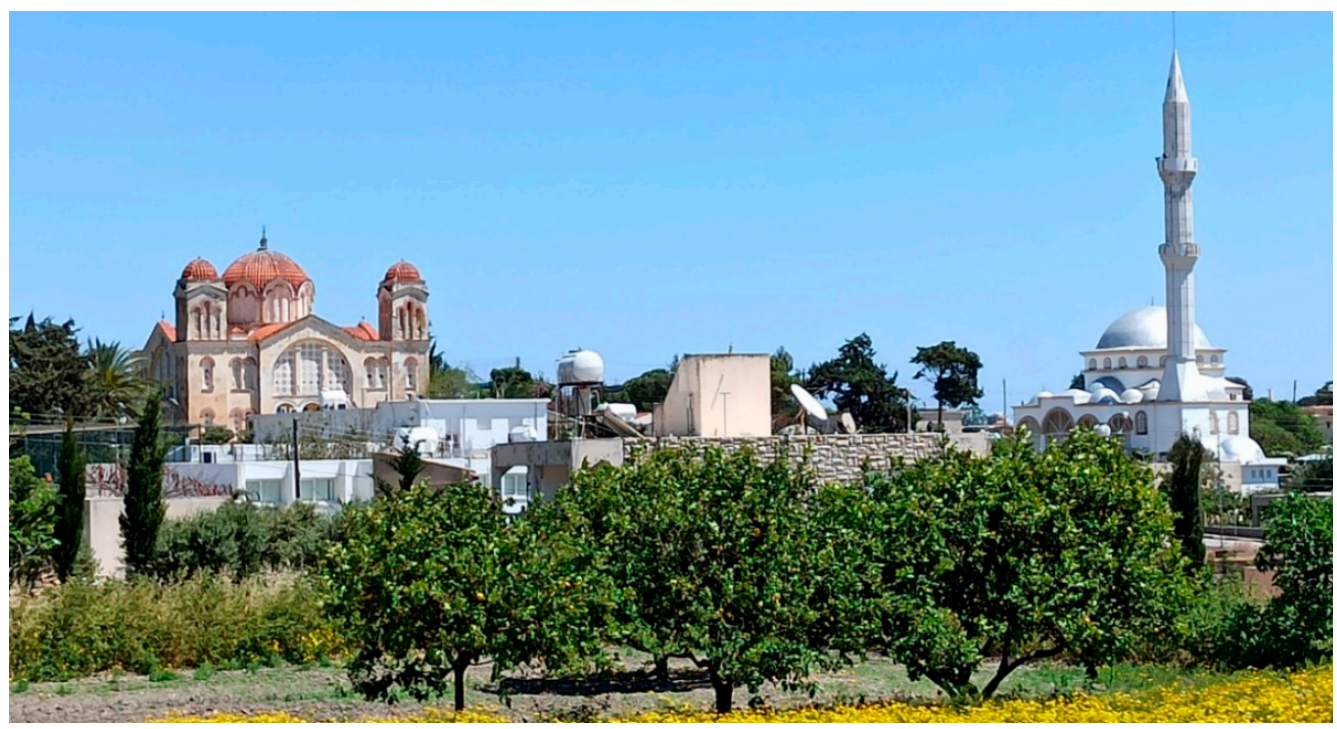

(b)

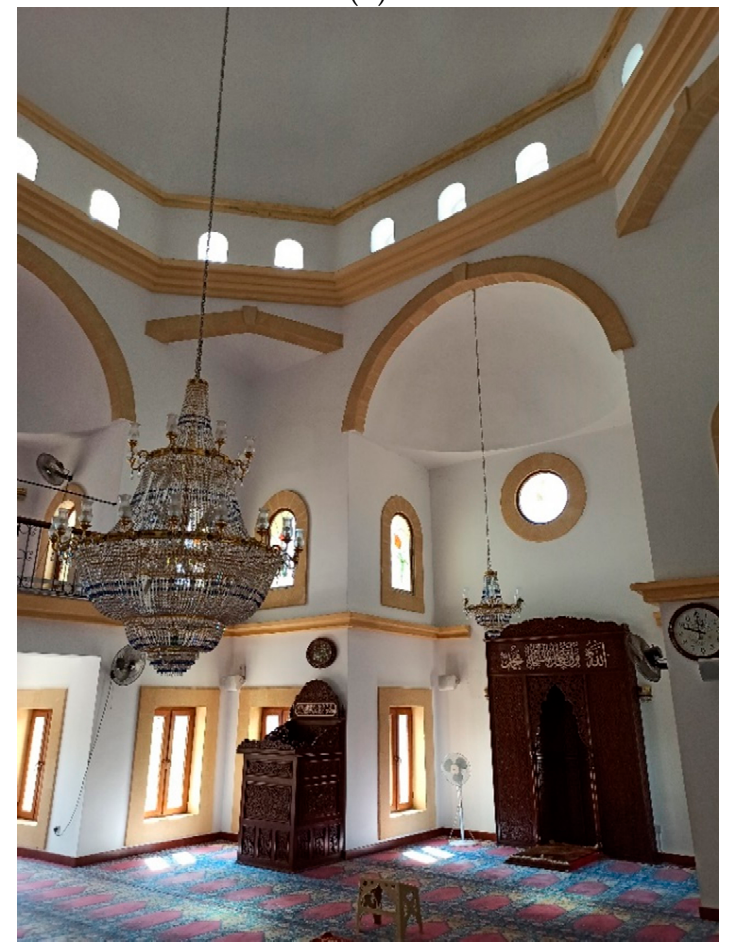

(c)

Figure 9. (a) Neo-Ottoman type B mosque and Nurettin Ersin Paşa mosque, gallery-floor plan (drawing by authors and Mojtaba Karimnezhad, based on a plan from the Evkaf Construction Department). (b) Yedikonuk/Ephtakomi, view from north-west onto the new neo-Ottoman mosque (type B; 2006/2008) on the right, and onto the former church of St. George (-1974)/former mosque (1974-2008) on the left (photo: authors). (c) Doğanköy (Kyrenia), neo-Ottoman type B mosque, 2012, view onto the mihrab (photo: authors). 


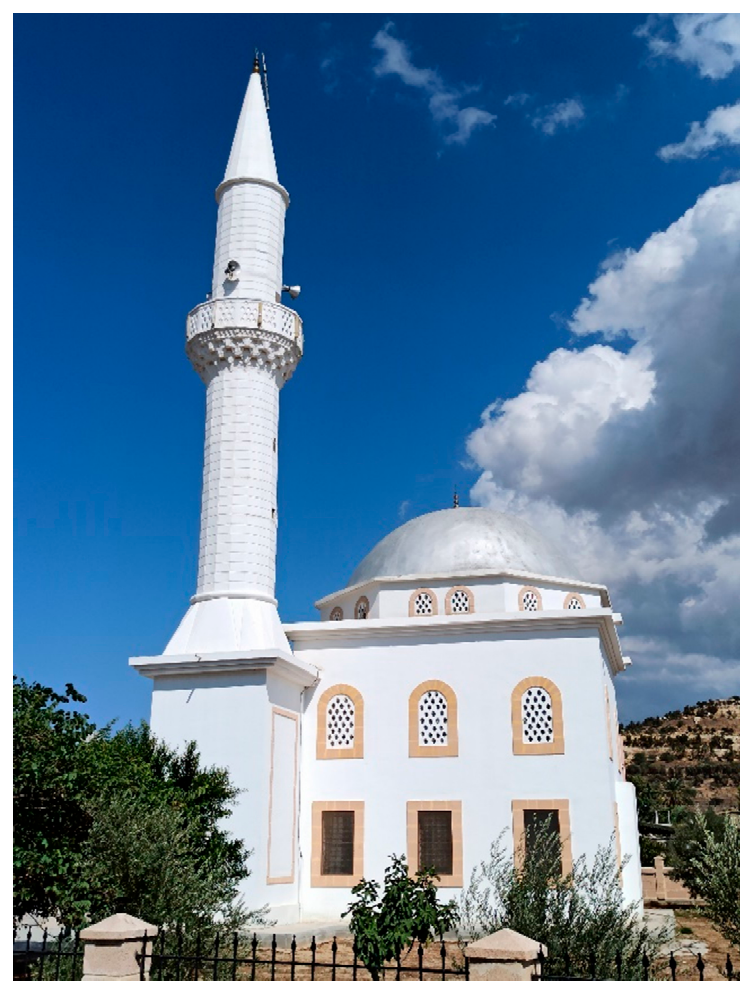

(a)

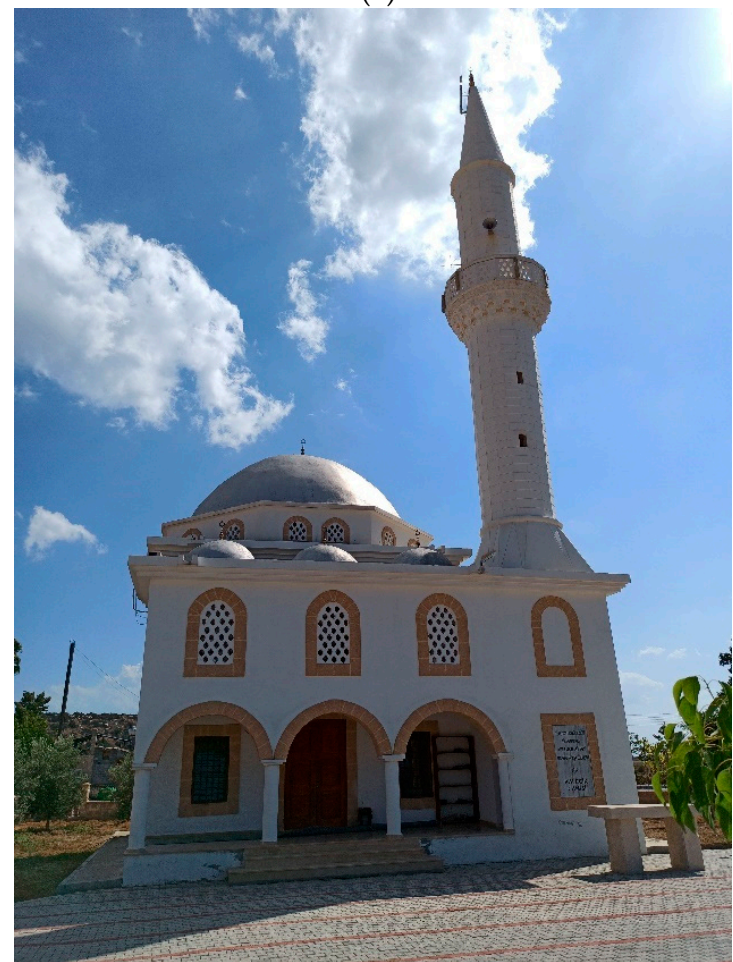

(b)

Figure 10. Kaleçik/Gastria, neo-Ottoman type A mosque, 2013: (a) exterior of the qibla wall on the right; (b) arcaded entrance portico (photo: authors).

Although the planning particulars (design, construction, choice of location, etc.) remain partially unclear, it is, as already indicated above, a top-down process with the designs provided from Turkey. According to the Evkaf Construction Department, the local population is not involved in the decision making about the choice of a specific design. The village committees can only apply for the building of a mosque. Thus, potential design 
preferences of the locals—of the pre-1974 population and of the post-1974 immigrants-do not play an immediate role.

Therefore, with types B and A, a rather ostentatious neo-Ottoman imagery was spread throughout the island's north, certainly acting as an element of 'soft power' as Seibert (2015) defines it for other cases of 'mosque-building diplomacy'. In our opinion, they are possibly a visual link to Turkey's policies of, as Zencirci coins it for the case of Turkey, a 'reproduction of Turkish national identity along Ottoman-Islamic lines' (Zencirci 2014, p. 3). Certainly they are, however, a visual architectural proof that Turkey's policies of raising 'pious generations' (Sonmez 2021) have also been affecting North Cyprus through religious place making, ${ }^{25}$ which considerably increased the visibility of Islam in North Cyprus with its rather Anatolian than Cypriot appearance, and also through the absolute size of the buildings.

This neo-Ottoman imagery culminated in the design of the Hala Sultan mosque in Haspolat/Mia Milia (Figure 1, Nr. 12). ${ }^{26}$ In 2012, the Cyprus Science, Ethics and Social Assistance Foundation began to plan and build the first religious vocational high school in North Cyprus, after the last religious school had been opened in 1932 and closed in 1949 (see introduction). The Hala Sultan Divinity College was completed in 2013 in NicosiaHaspolat as an essential element of a traditional külliye. ${ }^{27}$ The central element of such a religious complex is a mosque which was begun in 2013 (Dayığlu and Hatay 2014, pp. 158-59), financed by the Turkish Diyanet, and completed in $2019 .{ }^{28}$ The Hala Sultan Mosque within the complex of the Divinity College was inspired by the Selimiye mosque in Edirne. ${ }^{29}$ It can be defined more precisely as a smaller replica (An 2016, p. 10).

The name 'Hala Sultan' refers to the foster aunt of the prophet (hala = aunt). Her shrine is venerated in the Hala Sultan Tekke at Larnaca (Bağişkan 2009, pp. 51-52), and thus refers to the beginnings of Islam in Cyprus in the 7th century. Additionally, we suspect that the reference to the Selimiye in Edirne, which was commissioned under Selim II, the conqueror of Cyprus, is hardly a coincidence. Indirectly, this is institutionally admitted by mentioning that 'this building establishes an important link between the TRNC and Turkey'. ${ }^{30}$

However, despite this top-down religious place making, with its retro-imagery and its probable religious-political symbolism, despite the size and 'otherness' of these mosques, it needs to be emphasized that Christian Orthodox churches in Cyprus had demonstrated a similar development in retro-imagery and religious-political symbolism already since the 1930s that was linked to the wish of the Greek Cypriot population for Enosis, the union with Greece, which stood in opposition to the British colonial authority (see introduction, and Kiessel and Tozan 2014, pp. 167-69, figs. 9 and 13). Furthermore, although this recent imagery may be originally foreign to Cyprus-as was once also the Gothic style, the form of Latin religious place-making of the Frankish Lusignan - these spaces may nevertheless fulfill their function as spiritual places very well.

\subsubsection{Resilience of the Modern and of the Cypriot Vernacular}

In 2012, Near East University in Nicosia and Eastern Mediterranean University in Famagusta decided to construct campus mosques (Dayığlu and Hatay 2014, p. 162). The building in the NEU campus is currently under construction, but reveals already clearly a monumental retro-style. In contrast, the Selim II mosque in the EMU campus, designed in Turkey, ${ }^{31}$ funded by the Turkish state, and completed in 2017, is equipped with a pyramidal roof structure, four triangular facades, and a detached campanile-style minaret (Figures 1 and 11a,b). Its mihrab niche is, unusually for mosques in Cyprus, naturally and indirectly lighted, thus emphasizing the spiritual center of the building. The modern design, in the form of a tent, is unique in Cyprus, and also internationally it can be observed only in a few buildings, such as the King Faisal mosque in Islamabad (1966/86), designed by Vedat Dalokay (Hagedorn 2005, p. 592), that is said to reflect an Arabic Bedouin tent. ${ }^{32}$ Another case is the national mosque of Malaysia (1963-65). ${ }^{33}$ Given the strong similarity between the buildings in Famagusta and Islamabad, and given the fact that the latter has been designed by a well-known Turkish architect, it may be assumed that the inspiration for the campus 
mosque is the building in Islamabad. Despite its Ottoman name (Selim II.), the abstracted tent of the campus mosque probably refers to the early Islamic community, hence more generally to Islam, compared to the previously discussed mosques with their Neo-Ottoman imagery. The tent is possibly an intended metaphor that signifies moving across different Muslim countries and cultures, and it is certainly a more international design concept, considering that it is the mosque of a university that attracts international students.

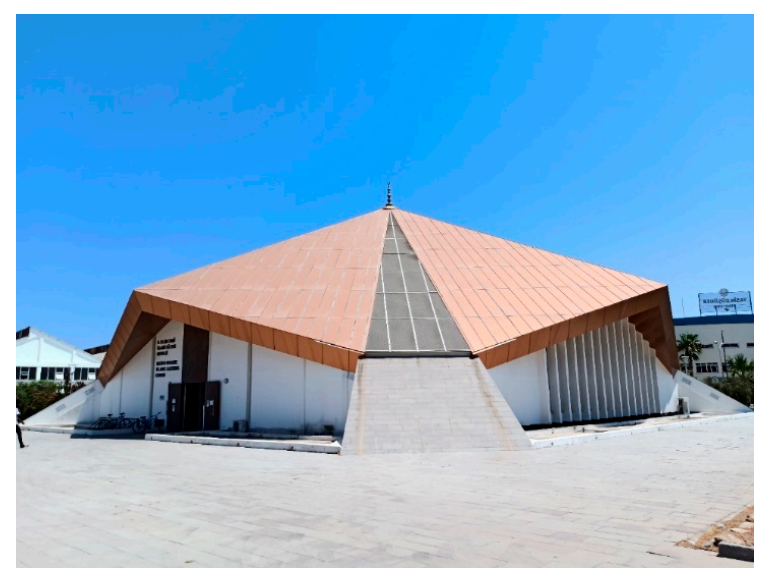

(a)

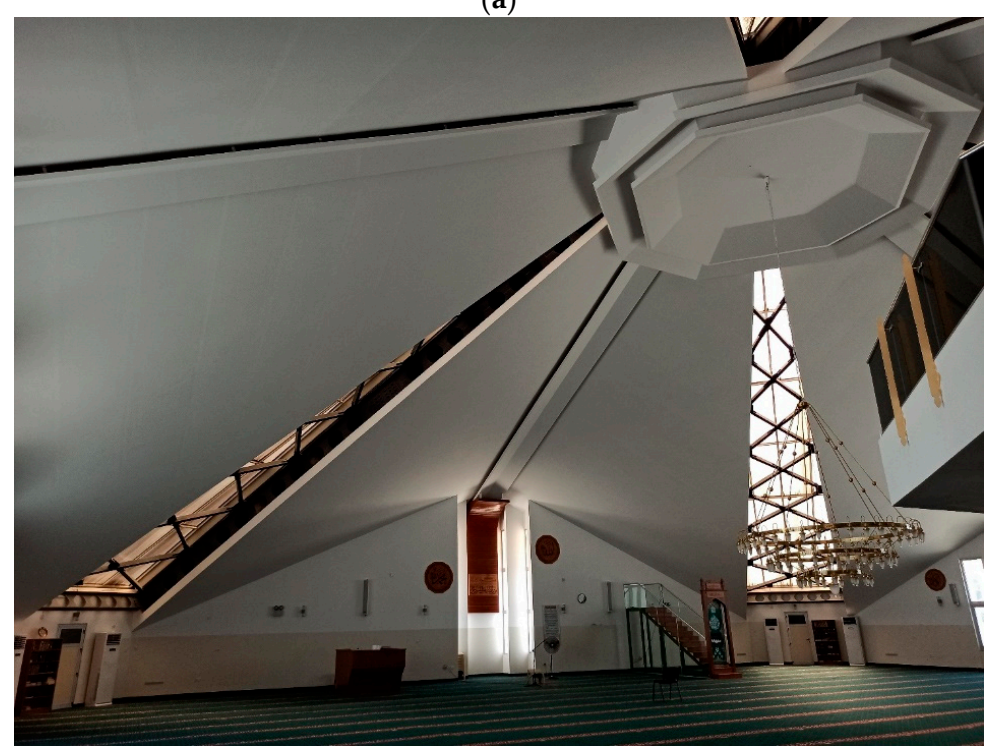

(b)

Figure 11. (a) Famagusta, Selim II mosque on the EMU campus, 2017, entrance and lateral facades (photo: authors). (b) Famagusta, Selim II mosque on the EMU campus, 2017, view onto the mihrab niche (photo: authors).

The Cypriot vernacular mosque type from the decades before 1974 re-emerged, for example in 2016/17 in the form of a mosque in Akova/Gypsou (Figures 1 and 12a,b). It is a rather inconspicuous rectangular hall consisting of five bays that are divided by four inner pointed arches that span from the prayer to the front wall. It is covered by an asymmetric saddle roof and features an arcaded front portico with five pointed arches that reflect the inner five bays. The size of the minaret, however, is relatively large, similarly to the minaret additions to older mosques that were discussed earlier. Since 2015, this standardized neo-vernacular type $C$ and the only slightly different type D (Figure 12c), the designs of which were created by the Evkaf Construction Department itself (contrary to the neo-Ottoman types A and B), and which deliberately refer back to the vernacular Cypriot type, have been applied so far in seven smaller communities, with the financial support 
of Turkey. ${ }^{34}$ Thus (Turkish) Cypriots, on an institutional level, have become again more involved in the planning of religious place making.

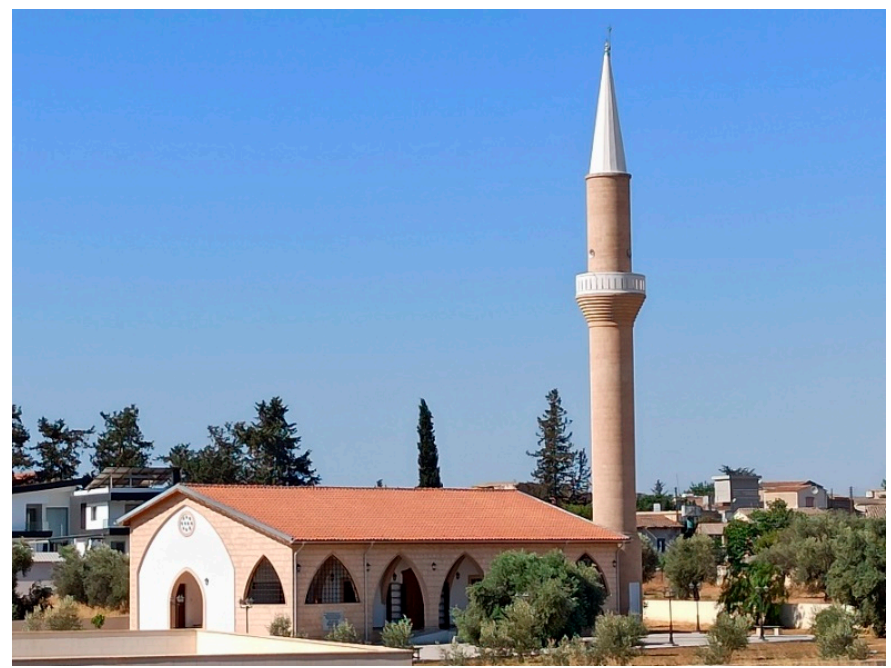

(a)

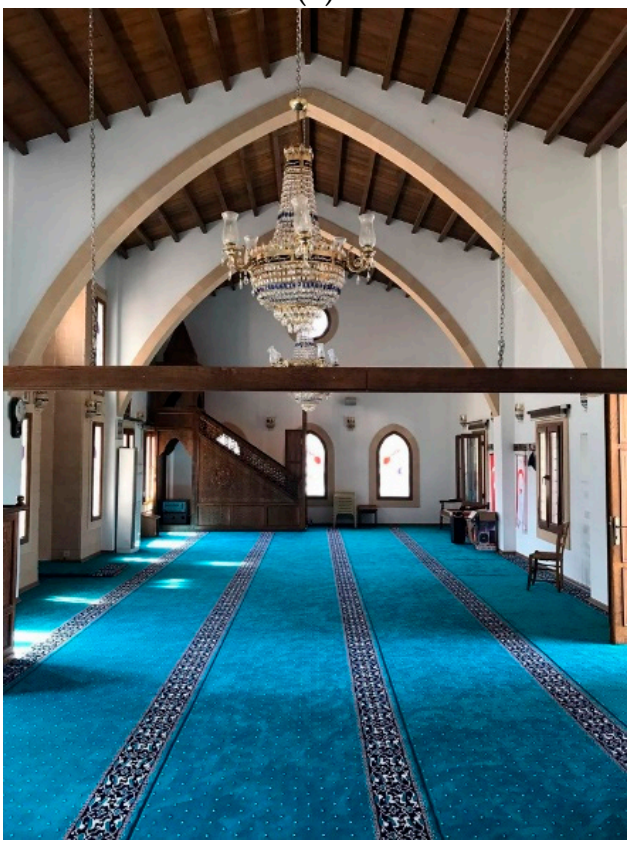

(b)

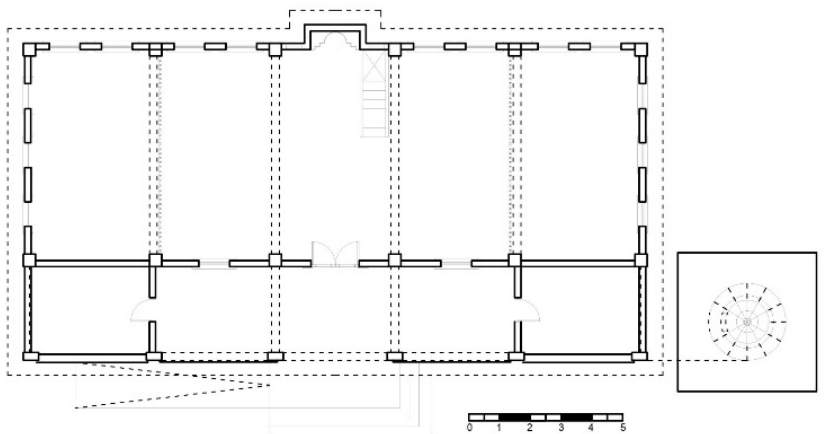

(c)

Figure 12. Akova/Gypsou, neo-vernacular mosque, type C, 2016/17: (a) entrance façade; and (b) interior (photo: authors). (c) Neo-vernacular mosque, type D, plan (drawing by authors and Mojtaba Karimnezhad, based on a plan from the Evkaf Construction Department). 


\section{Main Results and Conclusions}

Concerning the visible aspects of sacred Muslim buildings in Cyprus, we may argue that the design of mosques was not considerably affected by the change from Ottoman to British control in 1878, neither concerning plan typology, nor size, nor decoration. The case of the 'North-African' Sarayönü mosque in Nicosia is the proverbial exception that confirms the general rule. As we have noted, the number of newly built and fully rebuilt mosques increased noticeably between about 1880 and 1920, a fact which indicates a certain financial potency of the agents involved. Yet, the general trend-with a few exceptions in larger towns-is an inconspicuous architecture of the vernacular type, usually without minarets. At a time when Turks in Cyprus identified themselves as Ottomans or Muslims rather than Turks, this modest architecture can be best understood as places of functionality for the gathering of Muslim (village) communities. In our opinion, more profound meanings (invisible aspects) cannot be observed.

Church architecture played a role in the conflict with the colonial administration, reflecting "Greekness" through a revival of Byzantine typologies since the 1930s. Mosque architecture, however, in the form of several newly built mosques with minarets, and through the addition of minarets to existing mosques, did not reflect the meaning 'Turkishness' before the later 1960s, if at all. The general trend towards a secular Turkish nationalism among Turkish Cypriots since the 1920s probably prevented a strong symbolism of Muslim religious architecture, compared to the Orthodox churches. Therefore, the 1920s are not a visible architectural turning point, nor a turning point of meaning.

However, the year 1974, and the following division of Cyprus into the Republic of Cyprus and the internationally not recognized Turkish Republic of North Cyprus, as a general turning point in the political and cultural history of the island eventually also affected mosque architecture. Based on various sources, we have singled out three visible developments in the Turkish north before 2002: a widespread upgrading of existing village mosques with minarets, the (re-) introduction of the dome to mosque design in the early 1990s, and the introduction of a rather ostentatious neo-Ottoman mosque morphology in the late 1990s, predominantly financed by Turkey. These changes led to a greater visibility of Islam in North Cyprus with a rather Anatolian than Cypriot appearance due to the neo-Ottoman morphology. The changes likely reflect developments in Turkey since the 1980s where, according to Zencirci (2014), the traditional heritage discourse of secular nationalism made way for a new interpretation of national identity that fused 'Turkism' with Islam.

We argue that the following distribution of the neo-Ottoman imagery of the mosque types A and B in the north after 2002 (Figure 1) and the recent replica in Nicosia-Haspolat of the 16th-century Selimiye mosque are visual proof that Turkey's policies of raising 'pious generations' (Sonmez 2021) have also been affecting North Cyprus through religious place making. This view is supported by the top-down process of planning, with designs provided by Turkey. As a consequence of this process, the design preferences of the local population remain in the dark-something that could be a worthwhile focus for a future research project.

This place making, with its rather Anatolian appearance, considerably changed the 'material landscape' of the north of Cyprus and 'helped to make Islam more visible and tangible', as Hammond puts it for the case of Eyüp's transformation in Istanbul during the 1990s and 2000s (Hammond 2016, p. 142). Moreover, because these buildings have already taken roots, they might-using an expression of Hammond-'stabilize contested discourses of identity, heritage, and belonging' (Hammond 2016, p. 142).

While such place-making policies probably do not affect much the largely secular Turkish Cypriot population-nor probably the later generations of the early Turkish immigrants-the neo-Ottoman landscape also potentially works as an expression of the Turkish presence on the island and therefore of power, comparable with the Muhammed-Ali mosque (1824-48) in Cairo, which, by its classical Ottoman style, was meant to emphasize the affiliation of Cairo to the (late) Ottoman empire (Hagedorn 2005, p. 593). 
Several recent buildings are signs of the resilience of a modern design approach and of the Cypriot vernacular architecture, namely the Selim II mosque on the campus of the Eastern Mediterranean University and seven neo-vernacular village mosques. The latter revive the traditional Cypriot mosque type and were carefully designed by the local Evkaf Construction Department. Through them, (Turkish) Cypriots became involved more intensively in the planning process on an institutional level. All of these buildings demonstrate an architectural language with less political-religious symbolism. The fact that these mosques were also financed by Turkey probably indicates a more diverse approach to Turkish religious place making than the visually dominant neo-Ottoman landscape suggests at first sight.

Author Contributions: Conceptualization, data curation, methodology, visualization, writingoriginal draft, writing — review \& editing: M.K. and A.T. All authors have read and agreed to the published version of the manuscript.

Funding: This research received no external funding.

Institutional Review Board Statement: Not applicable.

Informed Consent Statement: Not applicable.

Data Availability Statement: Main data on mosque architecture and statistics used in this article derives from the cited literature, and from the Evkaf Construction Department (2021).

Acknowledgments: Evkaf Construction Department (=Vakıflar Idaresi-Inşaat Şube Müdürlügü), Nicosia, North Cyprus. Construction company Kurtsan Inşaat, Famagusta, North Cyprus. Mustafa H. Altan, former director of the National Archive of North Cyprus. Project Affairs Directorate (Proje Işleri Müdürlüğü), Eastern Mediterranean University, Famagusta, North Cyprus. Mojtaba Karimnezhad (MSc.IntArch), research assistant Faculty of Architecture, Eastern Mediterranean University, Famagusta, North Cyprus (drawings).

Conflicts of Interest: The authors declare no conflict of interest.

\section{Notes}

Realized in 1932 and closed in 1949 due to lack of students, see An (2016, p. 7).

See for the hotel: Kiessel (2019, p. 288 note 74).

On the renaming: Keshishian (1990, p. 174).

While three further mosques, including the Nurettin Ersin Paşa mosque in Kyrenia, completed in 1999, were built by other foundations.

5 Especially after 1983, when the Turkish Republic of North Cyprus (TRNC) was declared, which is recognized only by Turkey.

6 There were 49 mosques built under the supervision of the Evkaf Construction Department, in addition to the Polat Paşa, the Selim II, and Hala Sultan mosques in Famagusta and Nicosia-Haspolat from 2003, 2017, and 2019, respectively, built by other foundations.

7 See above on the development of a Turkish identity among Turkish Cypriots (especially: Hatay 2008, pp. 148-49; Nevzat and Hatay 2009, pp. 917-19).

8 The domed square unit typical of Ottoman-Anatolian mosque architecture goes back to the 14th century (see Hillenbrand 2010, pp. 257-58).

9 For further images, see https://en.wikipedia.org/wiki/Arab_Ahmet_Mosque; https://en.wikipedia.org/wiki/Hala_Sultan_ Tekke (accessed on 22 October 2021).

On the Selimiye mosque, Edirne, see Hillenbrand (2010, pp. 264, 266, fig. 200), and for further images see https://www.archnet. org/sites/1941 (accessed on 22 October 2021).

For images, see https: / www.lefkosabelediyesi.org/tarihi-ve-turistik-yerler/sarayonu-camii (accessed on 22 October 2021).

For the major towns, such as Nicosia, the internationally known names are used. As for the villages, the Turkish name is put first, followed by its Greek equivalent if a village is located in North Cyprus, whereas the Greek name is put first, followed by its Turkish equivalent if the location is in the Republic of Cyprus.

13 See for Photiadis's church building activity in the next section.

14 See also An (2016, pp. 8-9), who mentions the addition of minarets to the mosques of Krini and Agridi. 
Bağişkan (2009), who usually provides details about planning processes based on the data retrieved from the Evkaf archive, does not mention a lack of financial means or other reasons that might have delayed the construction of those minarets to the years after 1974.

See the image on http:/ / www.kktcdinhizmetleri.com/tr/camilerimiz (accessed on 27 July 2021).

According to the Evkaf Construction Department 2021 and according to http:/ / www.kktcdinhizmetleri.com/tr/camilerimiz (accessed on 27 July 2021), it was built in 1982.

See further images on https:/ / www.kibrispostasi.com/c35-KIBRIS_HABERLERI/n117167-Kibrista-dinler-arasi-iletisim (accessed on 27 July 2021).

Its design goes back at least to 1996, according to http:/ / www.kktcdinhizmetleri.com/tr/camilerimiz (accessed on 20 October 2021).

See on the Selimiye mosque, Hillenbrand (2010, pp. 264, 266, fig. 200), and for further images see https:/ /www.archnet.org/ sites/1941 (accessed on 22 October 2021).

It is also possible to read the building as a reduced version of early Ottoman mosques, similar to those in Bursa, where three fully domed spaces (instead of semi-domed "exedrae") flank the central space and form an inverted "T". See Stierlin (1998, pp. 85-86, 92).

See also Hammond (2016, p. 142) on Eyüp's transformation in contemporary Istanbul during the 1990s and 2000s that helped 'to make Islam more visible and tangible'.

Information is from the construction company Kurtsan Inşaat, Famagusta, and from the Evkaf Construction Department, Nicosia (2021). http:/ / www.kktcdinhizmetleri.com/tr/camilerimiz (accessed on 27 July 2021).

For religious place making (in a Muslim-majority context) the development of the religious material landscape (mosques, medreses, tekkes, cemeteries) and the secular built environment (for example hamams, bazaars and hans), the maintenance and restoration of these landscapes, religious rituals such as pilgrimage, social rituals and tourism may play a role, see Hammond (2016, pp. 18-22). For images see https:/ /tdv.org/tr-TR/proje/kktc-lefkosa-hala-sultan-camii/ (accessed on 27 July 2021).

A complex of buildings belonging to a pious foundation (vakıf) the center of which is a mosque. Includes usually a school (medrese). http:/ / www.kktcdinhizmetleri.com/tr/camilerimiz (accessed on 27 July 2021). https://tdv.org/tr-TR/proje/kktc-lefkosa-hala-sultan-camii/ (accessed on 27 July 2021); for images of the Selimiye mosque in Edirne see https:/ / www.archnet.org/sites/1941 (accessed on 22 October 2021). http:/ / www.kktcdinhizmetleri.com/tr/camilerimiz (accessed on 27 July 2021).

Information is from the Project Affairs Directorate (Proje Işleri Müdürlüğü), Eastern Mediterranean University, Famagusta (2021). https:/ /www.pakistanembassytokyo.com/content/faisal-mosque-islamabad (accessed on 27 July 2021).

https://mosqpedia.org/en/mosque/305 (accessed on 27 July 2021).

Information is from Evkaf Construction Department, Nicosia, and Kurtsan construction, Famagusta (2021).

\section{References}

An, Ahmet Djavit. 2016. The Development of Turkish Cypriot Secularism and Turkish Cypriot Religious Affairs. Eastern Mediterranean Policy 8: 1-11. Available online: https://cceia.unic.ac.cy/wp-content/uploads/EMPN_8.pdf (accessed on 27 July 2021).

Asmussen, Jan. 2008. Cyprus at War. Diplomacy and Conflict during the 1974 Crisis. London and New York: I.B. Tauris.

Bağişkan, Tuncer. 2009. Ottoman, Islamic and Islamised Monuments in Cyprus. Nicosia: Cyprus Turkish Education Foundation.

Coureas, Nicholas, Gilles Grivaud, and Chris Schabel. 2012. Frankish \& Venetian Nicosia 1191-1570. In Historic Nicosia. Edited by Michaelides Demetrios. Nicosia: Rimal Publications, pp. 111-230.

Dayıŏlu, Ali, and Mete Hatay. 2014. Cyprus. In Yearbook of Muslims in Europe-Volume 7. Edited by Jorgen S. Nielsen, Ahmet Alibašić and Egdūnas Račius. Leiden: Brill, pp. 153-75.

Evkaf Construction Department (=Vakıflar Idaresi-Inşaat Şube Müdürlügü). 2021. Verbal and Written Information on Construction Processes, -Details and -Statistics, Kindly Provided to the Authors. General Contact. Available online: http:/ /www.evkaf.org/ site/default.aspx (accessed on 20 October 2021).

Grabar, Oleg. 2005. Die Moschee. In Islam. Kunst und Architektur. Edited by Markus Hattstein and Peter Delius. Köln: Könemann, pp. 44-45.

Hagedorn, Annette. 2005. Architektur und Kunst. In Islam. Kunst und Architektur. Edited by Markus Hattstein and Peter Delius. Köln: Könemann, pp. 592-99.

Hammond, Timur Warner. 2016. Mediums of Belief: Muslim Place Making in 20th Century Turkey. Ph.D. thesis, University of Los Angeles, Los Angeles, CA, USA. Available online: https:/ / escholarship.org/uc/item/90w4p389 (accessed on 18 October 2021).

Hatay, Mete. 2008. The problem of pigeons: Orientalism, xenophobia, and a rhetoric of the 'local' in North Cyprus. The Cyprus Review 20: 145-72.

Hatay, Mete. 2015. 'Reluctant' Muslims? Turkish Cypriots, Islam, and Sufism. The Cyprus Review 27: 43-63. 
Hillenbrand, Richard. 2010. Islamic Art and Architecture. London and New York: Thames \& Hudson.

Ionas, Ioannis. 2003. La Maison Rurale de Chypre (XVIIIe-XX Siècle). Aspects et Techniques de Construction, 2nd ed. Nicosia: Centre de Recherche Scientifique de Chypre.

Keshishian, Kevork K. 1990. Nicosia, Capital of Cyprus Then and Now, 2nd ed. Nicosia: Moufflon Book and Art Centre.

Kiessel, Marko. 2019. Famagusta on Cyprus and the Sea: Hotel Architecture, Urban Development and Tourism during the British Colonial and Early Postcolonial Period. In Famagusta Maritima. Mariners, Merchants, Pilgrims and Mercenaries. Edited by Michael J. K. Walsh. Brill's Studies in Maritime History. Leiden and Boston: Brill, vol. 7, pp. 264-96.

Kiessel, Marko, and Asu Tozan. 2014. Orthodox Church Architecture in the Northern Districts of Cyprus from the mid-19th century to 1974. Prostor, a Scholarly Journal of Architecture and Urban Planning 22: 160-73.

Markides, Diana. 2012. Nicosia under British Rule. In Historic Nicosia. Edited by Demetrios Michaelides. Nicosia: Rimal Publications, pp. 325-402.

Nevzat, Altay, and Mete Hatay. 2009. Politics, Society and the Decline of Islam in Cyprus: From the Ottoman Era to the Twenty-First Century. Middle Eastern Studies 45: 911-33. [CrossRef]

Papacostas, Tassos C. 1999. Byzantine Cyprus. The Testimony of its Churches, 650-1200. Ph.D. thesis, University of Oxford, Oxford, UK.

Rizopoulou-Egoumenidou, Euphrosyne. 2012. Nicosia under Ottoman Rule 1570-1878-Part II. In Historic Nicosia. Edited by Demetrios Michaelides. Nicosia: Rimal Publications, pp. 265-324.

Schaar, Kenneth W., Michael Given, and George Theocharous. 1995. Under the Clock. Colonial Architecture and History in Cyprus, 1878-1960. Nicosia: Bank of Cyprus.

Seibert, Thomas. 2015. Turkey's mosque-building diplomacy. Al-Monitor. Available online: https://www.al-monitor.com/originals/20 15/02/turkey-mosque-building-soft-power.html (accessed on 27 July 2021).

Sonmez, Mustafa. 2021. Turkey's religious agency grows even richer, more powerful. Al-Monitor. Available online: https://www.almonitor.com/originals/2021/05/turkeys-religious-agency-grows-even-richer-more-powerful (accessed on 27 July 2021).

Stierlin, Henri. 1998. Turkey. From the Selçuks to the Ottomans. Köln: Taschen.

Tastekin, Fehim. 2021. Erdogan furious as his Islamic ambitions stumble in Turkish Cyprus. Al-Monitor. Available online: https: / / www.al-monitor.com/originals/2021/04/erdogan-furious-his-islamic-ambitions-stumble-turkish-cyprus (accessed on 27 July 2021).

Tozan, Asu. 2008. Urbanization and Architecture in Cyprus as an Example of Colonial Modernization (1878-1960). Ph.D. thesis, Istanbul Technical University, Istanbul, Turkey. (In Turkish)

Zencirci, Gizem. 2014. Civil Society's History: New Constructions of Ottoman Heritage by the Justice and Development Party in Turkey. European Journal of Turkish Studies—Social Sciences on Contemporary Turkey 19: 1-20. Available online: http:/ journals. openedition.org/ejts/5076 (accessed on 27 July 2021). [CrossRef] 